\title{
Water tracing with environmental DNA in a high-Alpine catchment
}

\author{
Elvira Mächler ${ }^{1,2}$, Anham Salyani ${ }^{3}$, Jean-Claude Walser ${ }^{4}$, Annegret Larsen ${ }^{3,5}$, Bettina Schaefli ${ }^{3,6}$, \\ Florian Altermatt ${ }^{1,2}$, and Natalie Ceperley ${ }^{3}$ \\ ${ }^{1}$ Eawag: Swiss Federal Institute of Aquatic Science and Technology, Department of Aquatic Ecology, Überlandstrasse 133, \\ CH-8600 Dübendorf, Switzerland \\ ${ }^{2}$ Institute of Evolutionary Biology and Environmental Studies, University of Zurich, Winterthurerstrasse 190, CH-8057 \\ Zürich, Switzerland \\ ${ }^{3}$ Faculty of Geosciences and Environment, Institute of Earth Surface Dynamics, University of Lausanne, 1015 Lausanne, \\ Switzerland \\ ${ }^{4}$ Federal Institute of Technology (ETH), Zürich, Genetic Diversity Centre, CHN E 55 Universitätstrasse 16, 8092 Zürich, \\ Switzerland \\ ${ }^{5}$ Soil Geography and Landscape Group, Wageningen University, Droevendaalsesteeg 3, 6708 PB Wageningen, The \\ Netherlands \\ ${ }^{6}$ Geography Institute, University of Bern, 3012 Bern, Switzerland
}

Correspondence: Elvira Mächler (elvira.maechler@eawag.ch)

\begin{abstract}
Alpine streams are particularly valuable for downstream water resources and for ecosystem conservation. However, the details of where and when water is stored and released in the heterogeneous mountain environment are rarely known. The use of physico-chemical flow path tracers is particularly challenging due to the temporary accumulation and storage of water in the form of snow and ice. Alternatively, biological tracers might complement information on flow and storage of water, especially as the different microhabitats in Alpine aquatic systems are inhabited by characteristic organismal communities. In this study, we explored the potential of particles of environmental DNA found in the water (eDNA) to characterize hydrological flow paths and connectivity in an Alpine catchment in Switzerland. Between March and September 2017, we sampled water at multiple time points at 11 sites distributed over the $13.4 \mathrm{~km}^{2}$ Vallon de Nant catchment for genetic species information based on naturally occurring eDNA. The sites correspond to three different water source types and habitats (main channel, tributaries, and springs).

Comparison of typical hydrological tracers and eDNA with temporal evolution of streamflow revealed that in the main channel and in the tributaries, the change in streamflow, $d q / d t$, is strongly correlated with biological richness. In springs, electrical conductivity was found to have a positive but not as strong correlation with biological richness. At the catchment scale, our results show that biological richness as indicated by the diversity detected by eDNA samples. When streamflow is increasing, transport of additional, and probably terrestrial, DNA into water storage or flow compartments is occurring. Such processes include overbank flow, stream network expansion and retraction, and hyporheic exchange. In general, our results highlight the importance of considering the at-site sampling habitat in combination with upstream connected habitats to understand how streams integrate eDNA over a catchment and to interpret spatially distributed eDNA samples, both for hydrological and biodiversity assessments. We identify next steps to be addressed to use eDNA as an independent tracer of Alpine water sources and we provide recommendations for future observation of eDNA in Alpine stream ecosystems.
\end{abstract}


Keywords: snow melt, glacier melt, groundwater, Alpine, eDNA, hydrology, metabarcoding

\section{Introduction}

Alpine environments are water towers for lowland areas (Viviroli et al., 2007), are considered hotspots for biodiversity (Körner,

5 2002), and are likely disproportionately affected by climate change (Jacobsen et al., 2012; Grabherr, 2009). These mountain areas occupy complex topography and span a large elevation gradient, thus their physical environment varies tremendously compared to lowland areas, creating a landscape with an enhanced heterogeneity of water flow paths due to a strong seasonality of water inputs (from rain to snow to snow melt) combined with extreme physical variation, such as temperature, slope, aspect, and radiation. Channel networks in Alpine areas regularly expand and contract, because a large portion of streams are ephemeral (Godsey and Kirchner, 2014; van Meerveld et al., 2019). Besides providing the water for downstream ecosystems and anthropogenic water use (Nolin, 2012), this heterogeneity creates diverse habitats. Meanwhile, mountain areas are regarded as particularly valuable for conservation due to the potential for lower pressure of human impact, their potential to act as 'sentinels' of future consequences of change, and their heterogeneous physical environment (Füreder et al., 2002; Khamis et al., 2014).

Despite the importance of mountain water resources, many unanswered questions remain about hydrologic processes in mountain environments. A watershed collects water that has fallen as rain and snow, stores some of it (i.e., ground water, soil moisture, or snow) and releases it as streamflow, evaporation or transpiration over time. From a hydrological as well as from an ecological viewpoint, one central question to answer is from where stream water originates (Nolin, 2012; Cochand et al., 2019; McGuire and McDonnell, 2015). However, hydrologic processes are difficult to observe because they occur out of reach, for example in the atmosphere or the subsurface (McDonnell et al., 2007). There is an ongoing search for hydrologic tracers that decompose river water into its most recent storage compartment (glacier, snow, vegetation, soil, groundwater) and identify when it entered the stream network (Abbott et al., 2016; Blume and Van Meerveld, 2015; Williams et al., 2009; Mosquera et al., 2018).

Water in Alpine catchments varies tremendously in its physico-chemical properties, such as temperature, discharge, stable isotopes and electrical conductivity (E.C.). These properties offer clues to identify water flow paths, temporary water storage and its associated time scales (Zuecco et al., 2019; Tetzlaff et al., 2015; Penna et al., 2014; Klaus and McDonnell, 2013). E.C. can discriminate snowmelt, which has very low levels of sodium, from groundwater, which typically has much higher levels of solutes (Williams et al., 2006; Cochand et al., 2019; Kobierska et al., 2015). Water temperature, on the other hand, is not conservative, meaning that it changes along a water course, but it can provide valuable clues to separate surface water, which has a strong diel variation, and influxes of water from the subsurface with more consistent temperatures (Constantz, 1998; Comola et al., 2015; Hoehn and Cirpka, 2006; Westhoff et al., 2007; Selker et al., 2006). Stable isotopes of water have 
classically been used as tracers because they show a clear variation according to season and elevation in precipitation input. However, in high Alpine contexts, they often fall short in offering additional insights into dominant flow paths because the isotopic ratio of all potential water sources is dominated by the precipitation phase of incoming water (rain versus snow; Lyon et al. 2018; Beria et al. 2018; Penna et al. 2018).

Different biological habitats emerge because of the variations in physio-chemical properties, which determine the benthic communities living in specific places in streams (Brown et al., 2003; Milner and Petts, 1994; Ward, 1994). Additionally, characteristics of these habitats vary according to high temporal dynamics: a single disturbance event, for instance, such as a heavy rainfall event, can perturb a system with little predictable frequency (Malard et al., 2000; Smith et al., 2001). Even though these events may only result in short-term deviations, they affect the communities living within the stream, creating diverse biological communities reflecting variation in physio-chemical properties (Savio et al., 2015). Therefore, biological organisms and particles, such as diatoms (Pfister et al., 2009; Lan et al., 2019) or bacteria (Wang et al., 2017) show promise as tracers, specifically for connectivity of the stream network and between terrestrial and aquatic ecosystems.

In recent years, the use of environmental DNA (eDNA) has been proposed to monitor organisms in aquatic ecosystems (Valentini et al., 2016; Deiner et al., 2015; Bohmann et al., 2014), but has yet to be explored by hydrologists as an additional tracer. All organisms leave traces of their genetic material, or DNA, behind in the environment, which can be collected in environmental samples and analyzed by using molecular approaches. eDNA can detect communities of a broad taxonomic scale with the use of a single sampling technique in combination with the high through-put sequencing of a barcoding region (so called metabarcoding), which allows detection of genetic diversity approximately at the level of species. Artificially introduced DNA attached to particles has already been shown to be a reliable and useful hydrologic tracer (Dahlke et al., 2015; McNew et al., 2018; Foppen et al., 2013) and naturally occurring DNA has just started to enter into the repertoire of hydrologic tracers (Good et al., 2018; Carraro et al., 2018). We believe that eDNA metabarcoding holds enormous potential inform analysis of hydrologic flow paths and connectivity from multiple disciplinary perspectives. So far, eDNA studies have extensively used in aquatic systems (Belle et al., 2019), but rarely targeted alpine river systems (beside Thalinger et al. 2018). Moreover, the collection of time series to survey changes of eDNA are very limited (Bista et al., 2017; Beentjes et al., 2019).

In this study, we asked three interlocking questions regarding the usefulness of eDNA as a tracer from the perspective of a hydrologist searching for new tracers to tackle mountain hydrology but their answers would also benefit the biologist observing Alpine diversity. First, does eDNA discriminate between the three sampled water sources? Second, how do changes in physical water flow processes, reflected as hydrologic heterogeneity in space and time, affect the eDNA composition? And third, whether upstream tributaries and springs determine the eDNA signal in the main downstream channel? We monitored eDNA in an Alpine catchment in Switzerland with on-going hydro-meteorologic observations. From March to August 2017, we sampled 11 sites corresponding to three different habitats (main channel, tributaries and springs roughly corresponding to the idealized Alpine stream types proposed by Ward 1994 of kryal, rhithral, and krenal). On 11 sampling days, we observed the E.C., water temperature and stable isotope ratios of the water $\left(\delta^{18} \mathrm{O}\right.$ and $\left.\delta^{2} \mathrm{H}\right)$ and simultaneously collected eDNA from water. In addition, we continuously monitored discharge at the catchment outlet and meteorological parameters at 4 stations distributed across the catchment. Our study provides an initial assessment of the spatial and temporal heterogeneity of eDNA 
in an Alpine stream system, and an initial biodiversity benchmark. This is an important first step for use of eDNA as a tracer and provides concrete recommendations for sampling eDNA in Alpine streams.

\section{Methods}

\subsection{Site description}

5 The Avançon is the main stream in the Vallon de Nant catchment (Canton of Vaud, Switzerland, Fig. 1). The 13.4 km ${ }^{2}$ catchment ranges from $1200 \mathrm{~m}$ a.s.1. (46.25301 $\left.{ }^{\circ} \mathrm{N}, 7.10954^{\circ} \mathrm{E}\right)$ to $3051 \mathrm{~m}$ a.s.l. (Le Muveran). It has a dominant north exposition, with almost no direct sun during winter in its upper parts, allowing a small glacier (Glacier de Martinets, $0.36 \mathrm{~km}^{2}$, GLAMOS 1881-2018) to persist at relatively low elevation. The streamflow regime is of the so-called nivo-pluvial type (Aschwanden and Weingartner, 1985), with a monthly streamflow peak in June. The catchment lies over the north-western section of the Nappe de Morcles, which is a tectonic nappe fold with an amplitude exceeding $10 \mathrm{~km}$ and a prominent inverse limb, whose stratigraphy is completely reversed, from which the Vallon de Nant has been eroded, leaving a clayey Oligocence flysch at the upper surface (elsewhere, the bottom of the Nappe) with a low permeability (Thornton et al., 2018).

\subsection{Field collection}

\subsubsection{Instrumentation}

A stream gauging station in the Avançon defines the catchment of the Vallon de Nant. Discharge was measured using a VEGAPULS WL-61 optical height gauge (VEGA, Schiltach, Germany) over a geophone weir (installed by the Swiss Federal Institute for Forest, Snow and Landscape Research) and a determined rating curve (Ceperley et al., 2018). A network of four distributed meteorological stations (at 1253, 1500, 1780 and $2100 \mathrm{~m}$ a.s.1.) included precipitation and air temperature, mainly measured with Lufft-WS 300/400 (Fellbach, Germany), solar radiation with Apogee incoming radiometer (SP230, Logan, Utah, U.S.A.), mounted in an energetically autonomous wireless network with a GPRS connection (Sensorscope Sarl, Lausanne, Switzerland, Michelon 2017; Ingelrest et al. 2010). At a single point (1253 m a.s.l.), a MADD tipping bucket rain gauge provided back up measurements (Fallot 2013, Yverdon, Switzerland). Data from the Swiss automatic meteorological station network is used to gap fill the local observations (12 missing days in 2017, gap filled with stations Evionnaz, Les Diablerets, Sorniot-Lac Inférior, or Bex, Avançon, MeteoSwiss 2019). Water temperature was logged at most sampling sites with Hobo temperature/light pendants (Bourne, MA, USA).

\subsubsection{Hydrological parameters}

Water was sampled using $12 \mathrm{~mL}$ amber screw vials with a solid polypropylene cap and a silicone rubber/PTFE septa (BGB Analytik, Boeckten, Switzerland). Temperature and E.C. were measured simultaneously with water sampling using a WTW (multi-3510 with a IDS-tetracon-925, Xylem Analytics, Germany). When temperature was not measured at sampling, it was filled with an observation from the continuous water temperature log. When E.C. was not measured in the field, it was post- 
analyzed using a glass bodied $6 \mathrm{~mm}$ probe in the laboratory (Jenway 4510, Staffordshire, UK). Water was analyzed for stable isotope compositions of oxygen and hydrogen using a Picarro Wavelength-Scanned Cavity Ring Down Spectrometer (WSCRDS) 2140-i (Santa Clara, California, U.S.A.). Samples were injected a minimum of six times and the last three measurements were averaged to calculate a raw value. Values were corrected according to a standard curve determined with internal standards, which are regularly calibrated against international standards VSMOW (Vienna Standard Mean Ocean Water) and SLAP (Standard Light Antarctic Precipitation) of the IAEA (International Atomic Energy Agency). Delta units of isotope compositions are reported (Coplen, 1994).

A total of 135 composite rain samples were collected using funnels flowing into insulated bags at 3 locations corresponding to the rain gauges $(1253,1500$, and $2100 \mathrm{~m}$ a.s.l.) and emptied weekly or biweekly between June 2016 and November 2018. Between February 2016 and April 2018, 199 snow samples were collected in a semi-random distributed manner across the catchment and include the entire snow pack depth when possible. All available samples of precipitation were used to determine a local meteoric water line, which was used to determine the lc-excess, lc-ex, or offset from the LMWL:

$L=\delta^{2} H-7.82 . * \delta^{18} O-10.47$.

A positive value of lc-ex falls above the LWML and a negative one below, with significance in that offset determined according to the measurement error in the determination of both isotope concentrations (Landwehr and Coplen, 2006). The value of lcexcess reflects the source water and physical processes that occurred at the surface, with more negative values signifying more evaporation and condensation since precipitation, in general.

Baseflow is identified as the lowest value in a ten day moving window. The change in discharge over time, $d q / d t$, was determined as the slope of the linear regression of the highest resolution (10 minute) discharge over the antecedent 48 hour window and reported as $\mathrm{mm} / \mathrm{day}^{2}$. This method was retained after comparison with calculation of the average of hourly and daily steps and the total change over various time windows (6-120 hours) as the best solution to capture the high resolution of the variability in discharge (see supplementary material Fig. S1). It was calculated at the watershed outlet for the moment of time that each sample was collected.

Snow covered area was calculated as a ratio from 0 to 1 over the non-forested part of the catchment using 21 Landsat 8 images and 24 Sentinel 2 images between September 2016 and December 2017 (Michelon et al., 2018). A linear interpolation of the combined time series was used to provide a fractional area covered with snow per sampling date.

\subsection{3 eDNA Sampling}

eDNA filtration was performed directly in field. We filtered $250 \mathrm{~mL}$ of stream water on each of four filter replicates per site using GF/F filters ( $25 \mathrm{~mm}$ diameter, $0.7 \mu \mathrm{m}$, Whatman International Ltd., Maidstone, UK). Following filtration, we dried the filter by squeezing air through it, rolled the filter with tweezers, and stored the filter into a $1.5 \mathrm{~mL}$ tube following the description of Mächler et al. (2018). If it was not possible to collect $250 \mathrm{~mL}$ on a single filter, we used more filters until we reached the goal of $1 \mathrm{~L}$ filtered water per site. The tubes were transported on ice and were then stored at $-20{ }^{\circ} \mathrm{C}$. We implemented a negative filter control consisting of $1 \mathrm{~L}$ MilliQ water that was previously treated with UV-C light, before beginning sample collection in 
the field, to verify a DNA-free status of used materials. Sites were sampled in all cases except for extreme avalanche conditions, snow cover, and when dry.

\subsection{Metabarcoding laboratory procedure}

\subsubsection{Extraction of eDNA}

5 We extracted the DNA from the filters after all samples had been collected. We used the DNeasy® Blood and Tissue kit (Qiagen, Hilden, Germany) following the protocol for animal tissue besides a few changes (see supplementary material section S3.1). In order to reduce biases due to lab procedure, we extracted the samples in a random order. During extraction, we combined two of the four filter replicates, resulting in two extractions per sampling event at the individual sites. We included a negative extraction control, containing a previously with UVC light treated filter, for each batch of extractions, resulting in 8 extraction controls. The extracted DNA was stored at $-20{ }^{\circ} \mathrm{C}$ until further processing.

\subsubsection{Library preparation}

Generally, eDNA exists in low concentrations in the environment and in order to sequence the DNA, we need to capture and amplify the gene region of interest. In our study, we target a subsection of a previously identified barcoding region for eukaryote species (Hebert et al., 2003), a 313 base pair fragment of the cytochrome oxidase I gene (COI, Geller et al. 2013; Leray et al. 2013). We used the Illumina dual-barcoded two-step protocol to amplify and sequence our samples consisting of polymerase chain reactions (PCR), replicates to minimize stochasticity effects, implementation of additional controls, indexing, and pooling (see supplementary material section S3.2 for individual steps).

\subsubsection{Laboratory conditions and negative controls}

eDNA laboratory methods are optimized for the detection of low amounts of DNA and thus very sensitive to contamination. In order to reduce false-positives, we followed the previously described laboratory precaution for work with eDNA (Deiner and Altermatt, 2014; Deiner et al., 2015; Mächler et al., 2015). Reused field material, such as filter housings and syringes, was soaked 40 minutes in $2.5 \%$ sodium hypochlorite (i.e. bleach), rinsed with deionized water and treated with UVC light prior to the reuse in the field. Furthermore, four types of controls were sampled during the field (filtration) and laboratory procedure (extraction, PCR negative and PCR positive, see supplementary material section S3.3), which were run alongside the eDNA samples during the laboratory workflow and are later used for data cleaning.

\subsection{Molecular data processing}

\subsubsection{Bioinformatic analysis}

The main goal of the bioinformatic analysis is to remove errors due to sequencing techniques and regroup sequences into operational taxonomic units (ZOTUs). High through-put techniques produce errors during sequencing and in order to increase 
appropriate sequence identification, the resulting reads are cleaned and undergo an initial check for quality (see supplementary material section S3.4). We determined variations of the amplified DNA sequences and reduced the influence of sequencing errors with UNOISE3 (usearch v10.0.240, Edgar 2016). The detected sequence variants were clustered at $99 \%$ sequence identity to reduce diversity and to account for possible amplification errors. This clustering of the sequences is resulting in so called ZOTUs (i.e. zero-radius operational taxonomic units). In this sense, a ZOTU is a cluster of DNA sequences that are very similar $(99 \%)$ and can be seen as a rough proxy for species. As a final step, the ZOTUs were assigned to a taxonomic name if possible (blast 2.3.0 and usearch v10.0.240, tax filter $=0.9$ ).

\subsubsection{Data cleaning}

The three negative controls produced during the field and laboratory procedure were used to remove noise caused by contami-

nation and failed sampling. In a first step, we examined potential contamination after Evans et al. (2017) in the following way: For each ZOTU found in one of our negative controls, we calculated a relative frequency by dividing the sum of reads for an individual ZOTU by the sum of all ZOTUs in the negative controls, which was then used as a threshold to clean the field samples (see supplementary file S4). Any ZOTU with a frequency below the threshold was removed from further analysis. We then merged the two eDNA replicates for each sampling point and removed any samples that were below 20,000 reads (2 out of 107 samples), likely originating from errors in the field.

\subsubsection{ZOTU rarefaction}

A ZOTU is a cluster of very similar DNA sequences and a single ZOTU can be seen as a rough proxy for a species. The number of species, also called richness, is a simple measure of biodiversity in ecology. However, richness is strongly affected by the sampling effort (i.e. the higher the sampling effort, the more species that will be found). Therefore, in order to compare diversity measures between sites, data were rarefied, a method to standardize effort (Simberloff, 1978). The number of reads per sample is used as a proxy for sampling effort. Therefore, we also rarefied the data to the sequencing depth, or number of reads, of the lowest field sample (26,759 reads).

\subsection{Data analysis and statistics}

We use multivariate analyses to answer three specific questions: i) whether the origin of a water sample determines the specific composition of eDNA (section 2.5.1); ii) whether hydrological heterogeneity correlated with the eDNA as measured by the number of species entities (section 2.5.2); and iii) whether the contribution of springs and tributaries can explain the eDNA variation in the main channel (section 2.5.3). All statistical analyses were performed using R (R Core Team (2018), version 3.5.3) and the R package 'phyloseq' (McMurdie and Holmes 2013, version 1.24.2). 


\subsubsection{Differentiation of water origin through eDNA}

Our first question to test usefulness of eDNA as a tracer for the flow path of the water, was whether the eDNA composition varied according to water source, defined as the flow and channel environment. In the study catchment, we identified three characteristic environments, spring, tributary, and main channel. We assumed that each of these environments defined different habitats, which home different biological communities. Thus, we tested whether we can distinguish eDNA samples from the three sources based on the identity of the captured ZOTUs, or the identity of the detected eDNA sequences. Shared ZOTUs can originate from the original habitat or downstream transport of eDNA. For this analysis, we used a non-metric multidimensional scaling (NMDS, Kruskal 1964a) approach, an ordination method that represents pairwise comparisons, or rank orders, of sampling sites in a two-dimensional space. Sites clustered close together are more similar in terms of their ZOTUs than sites far apart, which enabled us to identify if communities detected with eDNA cluster according to water source or other water characteristics. We used weak ties (stress type 1) allowing to break ties where equal observed dissimilarities exist (Kruskal, 1964a). We calculated the stress of the NMDS after Kruskal (1964b) as a measure of how well the configuration matches the observed data. The NMDS was plotted for the individual sampling days separately, to observe the development of differences over the sampling season.

Dissimilarity measures based on ZOTU identities were calculated to do a pairwise comparison between sites. We used an unweighted UniFrac (Lozupone and Knight, 2005) as a dissimilarity input to the NDMS, which is based on the phylogenetic tree (i.e. the evolutionary relationships among ZOTUs based on their sequence similarity) of the ZOTUs. We further fitted measured environmental variables (elevation, E.C., temperature, total solar radiation, baseflow, snow cover area, $d q / d t, \delta^{18} \mathrm{O}$, and lc-ex) onto the NMDS ordination two-dimensional space with a commonly used method that maximized the correlation between the ordination and the corresponding environmental variables (function envfit, R package vegan, Oksanen et al. 2007, version 2.5-4).

\subsubsection{Hydrologic heterogeneity effects on eDNA}

Next, we tested how eDNA varied according to hydrologic heterogeneity, as indicated by the change in discharge at the catchment outlet, $d q / d t$, or subsurface exchange as revealed by changes in electrical conductivity (E.C.). We used richness, calculated for each individual sampling site and time point, as a simple measure of eDNA. We used a generalized linear mixedeffect model (GLMM, function glmer in the R package lme4, Bates et al. 2007) with ZOTU richness $(R)$ as the explanatory variable, change in discharge $(d q / d t, D)$ and the water source $(W)$ as fixed effects and the sampling site $(S)$ as a random effect. The univariate response variable $Y=R$ was modeled with vectors $X=[S]$ and $Z=[D, W, D W]$ of the explanatory variables associated with the fixed effect $(Z)$ and the random effect $(X)$. We assumed a Poisson distribution and the conditional mean $E(Y \mid X, Z)=\mu=g^{-1}(\eta)$ related to the linear predictor by a log-link function with inverse $h=g^{-1}$ (Crawley, 2012; Coxe et al., 2009). The identity of the sampling sites was defined as a random effect in an intercept model, to take by-sampling site variability into account. 
We compared the models with and without interaction of the two explanatory variables and selected the best one based on a $\chi^{2}$-test, classically used to compare model fits. Since change in discharge, $d q / d t$, was correlated with the opposite pattern in springs, we performed a second analysis where we replaced $d q / d t$ with E.C. $(E)$, in the above model, which is an indicator of the subsurface exchange that defines springs. E.C. was scaled and centered for the model due to large eigenvalue ratios.

\section{$5 \quad$ 2.5.3 Identification of water contributions}

In order to examine how many eDNA sequences the upstream springs and tributaries contribute to the richness in the main channel downstream, we calculated overlap in ZOTUs. We identified ZOTUs that are unique to samples from one water source, shared by only two, or all three water sources. If a ZOTU was only found in spring samples or in spring and main channel samples, but never in any tributary samples over the whole data set, the ZOTU origin was assigned to springs, and if only in tributaries or in tributaries and main channel samples but never in any spring sites, its origin was assigned to tributaries. The ZOTU's presence in the main channel did not influence this decision, since we assume the main channel contains the DNA of both tributaries and springs.

Next, we partitioned the ZOTUs in main channel samples into those originating from springs and tributaries, providing a count of how much springs and tributaries, respectively, are contributing to the main channel. We then plotted the relative contributions separately against $d q / d t$ and E.C., as these were previously identified as major drivers for richness. To confirm this relationship, we computed a generalized linear model (GLM) with the relative contribution $(C)$ as a response variable, $d q / d t, D$ and the origin of the ZOTU $(O)$ as explanatory variables:

$C=\beta_{0}+\beta_{1} \cdot D+\beta_{2} \cdot O+\epsilon$

where $\epsilon$ comes from a quasi-binomial error distribution. This choice results from i) binomial error distributions are appropriate for proportional variables; ii) our data set shows overdispersion, i.e. higher variability than what can be explained by the standard binomial error distribution. We compared the models with and without interaction of the two explanatory variables and selected the best model with a F-test. As before, we also tested a model with E.C. (E) as explanatory variable replacing $D$ :

$C=\beta_{0}+\beta_{1} \cdot E+\beta_{2} \cdot O+\epsilon$

\section{Results}

\subsection{Hydro-meteorological variables}

Annual precipitation in 2017 was $1760 \mathrm{~mm}$, which is close to the long term average of $1920 \mathrm{~mm}$ over the period 1961 - 2017 (minimum 1470 mm, maximum 2600 mm, MeteoSwiss 2011). Approximately one third of measured precipitation fell as snow in 2017 , or $50 \%$ over the whole catchment area as calculated from Rhires with a transition between $0^{\circ} \mathrm{C}$ and $2^{\circ} \mathrm{C}(\mathrm{Fig}$. 2 , MeteoSwiss 2011), snow melt peaked in early June, snow cover was reduced to $9 \%$ of the watershed area by July 1 (DOY 181), and reached $0 \%$ on August 18 (DOY 229). There was a particularly large rain event just before the third sampling date in 
July (DOY 207) and the stream flooded over bank in early August, creating a new channel between 1500 and $1600 \mathrm{~m}$ a.s.l. but was corrected within days before the first August sample day (DOY 215). Average daily air temperature across the catchment was above zero for most days after mid-May. The two tributaries ST and TT were dry in early (before DOY 136) and late season (after 164 and 220, respectively). The upper tributary (UT) was under the snow and inaccessible for the first sampling day (DOY 88).

E.C. shows distinct spatial patterns, both in terms of median observed values at given locations and in terms of the temporal range of E.C. values for individual locations (Fig. 3). In general, median values are higher in springs than at other sites, and generally higher at lower elevations; highest median E.C. values were observed in the lowest elevation spring (GS, median observed E.C. $268 \mu \mathrm{S} / \mathrm{cm}$, Fig. 3), lowest E.C. values in the two ephemeral tributaries (TT and ST, median of $159.35 \mu \mathrm{S} / \mathrm{cm}$ ). Compared to tributaries, springs typically show a narrow E.C. range (Fig. 3). The main channel shows mid E.C. values and also a narrow temporal range of E.C.values, which results from a mixing of sources (tributaries and springs) throughout the season. These patterns allow a first conclusion on the origin of water from the upper tributary (UT), which shows a high median value along with a narrow temporal E.C. range, i.e. it behaves like a spring; this points towards long subsurface flow paths for this sampling location. The highest E.C. range is observed for UR (from the glacier) with a high E.C. range (22.4-148.3 $\mu \mathrm{S} / \mathrm{cm}$ ), which results from the fact that the water from this sampling site has seasonally different origins (snow- and ice melt during the melt season, groundwater otherwise).

Water temperature is the best physico-chemical discriminator of the three types of sites (Fig. 3). Springs had the lowest and most consistent water temperature (median values between 4.7 and $6.5^{\circ} \mathrm{C}$, and no single above $7.5^{\circ} \mathrm{C}$ ). Tributaries, including UR, showed high water temperature variability $\left(8-21^{\circ} \mathrm{C}\right)$, and were considerably warmer. Points in the main channel had intermediary values (medians between 6 and $11^{\circ} \mathrm{C}$ ). Though our main channel sites had large diel flow fluctuations in summer, clear and turbid water, the temperature was significantly higher than typical kryal sites (maximum $4{ }^{\circ} \mathrm{C}$ ), suggesting that glacier melt is a relatively small contribution to the main stream flow. Tributaries (especially TT and ST) were dominated by extended snow-melt runoff and a large range of temperatures suggesting that they can be categorized as rhithral. Finally, our spring sites did have cool summer and warm winter temperatures, extremely high and consistent water clarity and constant flow conditions suggesting that they can be considered krenal.

Stable isotopes of oxygen $\left(\delta^{18} \mathrm{O}\right)$ and hydrogen $\left(\delta^{2} \mathrm{H}\right)$ were highly correlated and well within the range of precipitation (Fig. 3, supplementary material Fig. S02). The local meteoric water line (LMWL) is close to the standard global meteoric water line (GMWL). In general, values of isotopes in the main channel were intermediary to those in springs and in the tributaries, however the isotope ratio differences between the different sampling locations were not consistent enough for a simple 2 source mixing model using springs and tributaries, but show clearly the seasonal origin of water (from snow fall versus from rainfall) (Beria et al., 2018). The obtained results allow the following conclusions: i) The two ephemeral tributaries TT and ST had the most variation in stable isotopes, suggesting that they were composed mainly of snow-melt during part of the season (before June) and mainly of summer precipitation (rain) later. ii) The lowest spring (GS) most frequently had the highest value of $\delta^{18} \mathrm{O}$, indicating its reservoir might be fed mainly by summer precipitation. This is confirmed by the deviation of the GS isotope ratios from the LMWL, expressed as a more negative lc-excess, which suggests that out of all the samples, the water in the GS had 
undergone the most phase change (typical for summer rainfall undergoing evaporation) since entering the basin. HS and ST also had more negative values of lc-excess than most of the sites, however, none of the values of lc-excess are significant according to the definition in the original paper where it was defined (Landwehr and Coplen, 2006). Thus surface evaporation does not significantly affect the isotopic ratios in any of the sampling sites. There is little evidence that glacier melt makes up a large contribution of discharge.

Overall, the analysis of the physico-chemical tracers confirm the hypothesis underlying the sampling design that the different sites correspond to different water sources with typical seasonal tracer patterns resulting from different rain and snow inputs and from different subsurface flow paths. Accordingly, we can expect the seasonal and spatial biodiversity patterns observed at these sites to be at least partly explained by these different origins and water flow paths, and in turn, that eDNA observations might convey information on hydrological processes.

\subsection{High through-put sequencing}

The Illumina MiSeq run resulted in 12.5 M reads and 9858 ZOTUs after the bioinformatics pipeline, of which $2.9 \mathrm{M}$ and 9622 ZOTUs remained after removal of contamination and rarefaction (see Table S2 in the supplement for detailed information). Three percent (290) of ZOTUs had a taxonomic assignment to genus level (supplementary file S5), among these we find typical Alpine species such as Diamesa betrami, Podisima pedestris, Salamandra atra, Vipera berus, Lagopus muta and Rupicapra rupicapra that have previously described to be present in the Vallon de Nant (Freitag, 2009; Gattolliat et al., 2009; Helfer and Monney, 2009; Marchesi et al., 2009; Morard, 2009). We detected differences in ZOTU richness between the three surveyed water sources, with higher ZOTU richness in tributaries (mean $\mathrm{M}=936.95$, standard deviation $\mathrm{SD}=279.17$ ), compared to main channel $(M=676.43, S D=373.86)$ and spring sites $(M=340.33, S D=169.27)$. The variation in richness over time is high for sites in the main channel and tributaries, while sites in springs are more similar regarding number of ZOTUs found (Fig. 3), likely because eDNA and the detected diversity within a sample is influenced by the variation of the physical environment, which changes in time. Environmental variables (such as temperature, water chemistry, substrate, flow conditions) affect the availability of eDNA in the environment (Barnes and Turner, 2016; Strickler et al., 2015; Seymour et al., 2018).

\subsection{Differentiation of water origin by eDNA}

The NMDS plot, which uses pairwise comparisons of multidimensional data to represent data in two dimensional space, resulted in stress $=0.132$, indicating that the reduced dimensions represent the data fairly well (Kruskal, 1964a). While spring sites cluster slightly apart from main channel sites, this is not the case for tributary sites that are located at the intersection between main channel and springs (Fig. 4). The arrows indicate the direction of the fastest change in the environmental variables of E.C., $\delta^{18} \mathrm{O}$, water temperature and lc-ex, respectively, which were all significant (Table S6), and their length is proportional to their correlation with the ordination of the genetic data (Oksanen et al., 2007). As the arrow length represents, E.C. is the most important explanatory variable followed by water temperature and lc-ex and finally $\delta^{18} \mathrm{O}$ was the least important. The NMDS plots separated by sampling day show that in May and June (DOY 136 and 164), both tributaries and the main channel are more similar compared to later in the season (Fig. S3). The similarly low isotope values across all sites allow us to 
Table 1. Results from the generalized linear mixed model fit by maximum likelihood (Laplace approximation) for fixed effects, asterisks stand for the interaction. Note that the water source is a factor with three levels (main channel, spring and tributary).

\begin{tabular}{|c|c|c|c|c|c|}
\hline Model & Fixed effects & Estimate & Std. error & $\mathrm{z}$ value & P-value \\
\hline \multirow[t]{6}{*}{$\mathrm{dq} / \mathrm{dt}$} & Main channel (intercept) & 6.407 & 0.093 & 68.888 & $<0.001$ \\
\hline & $\mathrm{dq} / \mathrm{dt}$ & 1.791 & 0.026 & 69.582 & $<0.001$ \\
\hline & Spring & -0.637 & 0.152 & -4.192 & $<0.001$ \\
\hline & Tributary & 0.434 & 0.152 & 2.855 & 0.0043 \\
\hline & $\mathrm{dq} / \mathrm{dt} *$ Spring & -2.055 & 0.053 & -38.485 & $<0.001$ \\
\hline & $\mathrm{dq} / \mathrm{dt} *$ Tributary & -1.128 & 0.048 & -23.668 & $<0.001$ \\
\hline \multirow[t]{6}{*}{ E.C. } & Main channel (intercept) & 6.569 & 0.090 & 73.092 & $<0.001$ \\
\hline & E.C. & 0.201 & 0.010 & 20.335 & $<0.001$ \\
\hline & Spring & -1.183 & 0.149 & -7.946 & $<0.001$ \\
\hline & Tributary & 0.549 & 0.149 & 3.705 & $<0.001$ \\
\hline & E.C.*Spring & 0.156 & 0.024 & 6.517 & $<0.001$ \\
\hline & E.C.*Tributary & -0.027 & 0.021 & -1.272 & 0.203 \\
\hline
\end{tabular}

attribute early season homogeneity in the eDNA to the dominance of snowmelt, which flushes the system and reduces inter-site variability. In contrast, in late season (DOY 215), there was the highest range of water isotope values across all sites (Fig. 3), suggesting more diversity of water origin and flow path. However, the persistent clustering in DNA suggests that the flood event in early August (see Fig. S3) homogenized the eDNA community detection. Nevertheless, by August 9 (DOY 220), the upper part of the main channel, had already returned to a more distinct position in the ordination.

\subsection{Hydrologic heterogeneity effects on eDNA}

Since Alpine catchments are highly dynamic, the link between environmental variability in the different water sources and detected richness was pronounced: Both, change of discharge and E.C. are affecting the detected richness (Fig. 5a respectively $5 \mathrm{~b})$ and the best model included the interaction of the fixed effects for both the model with $d q / d t$ and the model with E.C.

10 (Table S3). The first model, including $d q / d t$, reveals that the fixed effects and their interaction are significant (Table 1, see Table S4 for results of random effects). However, water source is a factorial variable and the individual sources showed not the same response: The intercept (-0.637) and the slope (-2.055) for the spring samples are negative compared to the main channel, indicating a negative effect of $d q / d t$ on the richness detected in springs. The slope for tributary sites is slightly negative compared to the main channel sites but still resulting in a positive relationship of richness and $d q / d t$. The second model, including E.C. instead of $d q / d t$ as a fixed effect, identified all fixed effects and their interaction to be significant, except the interaction of E.C. and tributary sites; this level of the factorial variable water source is not related to E.C. 
Table 2. GLM results for response variables based on a t-test, asterisks stand for the interaction. Note that the origin of the ZOTU is a factor with two levels (spring and tributary).

\begin{tabular}{|c|c|c|c|c|c|}
\hline Model & Coefficients & Estimate & Std. Error & t value & P-value \\
\hline \multirow{2}{*}{$\mathrm{dq} / \mathrm{dt}$} & Spring (intercept) & -2.700 & 0.052 & -51.548 & $<0.001$ \\
& $\mathrm{dq} / \mathrm{dt}$ & -0.498 & 0.298 & -1.673 & 0.09724 \\
& Tributary & 1.386 & 0.061 & 22.685 & $<0.001$ \\
& Eq/dt*Tributary & 1.147 & 0.340 & 3.368 & 0.00106 \\
& Epring (intercept) & -2.377 & 0.270 & -8.790 & $<0.001$ \\
& E.C. & -0.001 & 0.001 & -1.255 & 0.212 \\
& Tributary & 1.416 & 0.064 & 22.063 & $<0.001$ \\
\hline
\end{tabular}

\subsection{Identification of upstream water contribution}

Over the whole sampling campaign, $79.2 \%$ of ZOTUs found in tributaries were recovered in the main channel, compared to $77.0 \%$ in springs (Fig. 6). Over all ZOTUs, we found 1374 ZOTUs (14.3\%) that were detected only in spring sites but never tributaries and 3221 ZOTUs (33.5\%) that were exclusively assigned to tributary sites. We were interested to see how much

5 springs and tributaries contribute to the sampling sites in the main channel and if this is driven by the same variables as the ZOTU richness, namely $d q / d t$ and E.C. (Fig. 5a, respectively 5b). The best model of change of discharge, $d q / d t$ included its interaction with the origin of the ZOTUs (Table S5). The relative contribution of ZOTUs is significantly affected by their origin, but only the contribution from ZOTUs originating in tributaries had a significant interaction with $d q / d t$, while no significant interactions were observed for ZOTUs originating from springs (Table 2, Fig. 6b). In contrast, the best model with E.C., which was more correlated with richness in springs, did not include interactions (Table 2, Fig. 6c).

\section{Discussion}

This study demonstrates for the first time the feasibility of detailed eDNA analysis in a comparable high Alpine environment with much lower species densities compared to lowland sites. Our results underline the complementarity of the information content of the observed physico-chemical variables and the biological variable eDNA as tracers. Like stable isotopes, temperature, and E.C, the eDNA measure of richness changed differently over the course of the season according to site. While springs were consistent and tributaries were highly variable, the main channel had an intermediary level of genetic diversity. In fact, locally observed species pool is known to be strongly influenced by single perturbation events (in particular floods) and the interpretation of corresponding readings requires thus detailed additional information on the state of the hydrologic system, as quantified in the present study by observed E.C., water temperature, stable isotopes of water and streamflow variations. eDNA, on the other hand, provides promising new insights into the temporal evolution of the connectivity of the stream network system, a key to assessing dominant hydrologic flow paths and model development. Below, we further expand on the hydrologic 
information that is potentially conveyed by eDNA observations and on the link between eDNA and the two variables that were identified to be the most strongly linked to corresponding observations, the change in discharge $d q / d t$ and E.C.

\subsection{Differentiation of water origin by eDNA}

The statistical analysis showed that the eDNA composition of the three habitats was indeed different, but not entirely distinct, which is in-line with a bacterial study of Alpine streams (Wilhelm et al., 2013). The overlap can be explained by either shared species compositions and/or the importance of flow characteristics such as discharge, which obscure the separation due to high hydrological connectivity between sites. We identified E.C. and temperature as the two most important drivers for the community clustering over all samples, corroborating previous, classical Alpine stream biodiversity work. By monitoring over a season, we were able to identify moments of greater and lesser connectivity according to the eDNA community dissimilarity. In July (D.O.Y. 193, 199, and 207), the greater dissimilarity was likely driven by snow melt events.

\subsection{Change in discharge affecting eDNA tracer}

There was a strong positive relationship between the change in $Q, d q / d t$, and detected richness in the tributaries and main channel. High discharge $Q$ events were products of either rainfall or snowmelt, and resulted in overland flow, expansion of the channel network and subsurface flow exceeding soil capacity further lengthening the channel (Chorley, 1978). This expansion put water in contact with additional surface areas from which eDNA was collected and resulted in a higher diversity. We assume, that these additional sources of eDNA lead to more transfer from terrestrial habitats into the water column than previously observed (Deiner et al., 2015; Ushio et al., 2017). However, when $Q$ decreased, there was an overall contraction of the network, reduced overbank flow, less exchange with the hyporheic zones and channel bank erosion, which led likely to less water sourceunspecific DNA in our record (Fig. 7). The tributaries with their variable nature, thus, can be considered the collectors of the ecohydrological system, collecting genetic diversity when they contain more water and as hydrologic connectivity increases. The richness at spring sites was, however, not correlated with $d q / d t$, likely because springs are unchanneled, thus their discharge is not directly linked to heavy flow events that control the tributaries and main channel. This is further supported by the observed positive relationship between $d q / d t$ and increased contribution of ZOTUs originating from tributaries but not from springs.

\subsection{Electrical conductivity affecting eDNA tracer}

Detected richness in springs is relatively stable through the seasons (as are stable isotopes and temperature); we even observe a slight negative relationship between richness and $d q / d t$. This is not surprising, as the springs have a relatively constant flow and stable surface area. However, E.C. varied over the season in springs, indicating elevated cumulative contact with subsurface substrate (Malard et al., 1999) which also correlated with increase richness. Our models suggest that, similarly to surface water, richness in springs is also increased by interaction with other habitats, in this case terrestrial. However, we found no positive relationship between E.C. and the contribution of ZOTUs to the main channel from spring habitats, indicating a relatively small contribution of eDNA from springs on the main channel, at least during our sampling season. The quantity of the contribution 
from springs to the main channel, in terms of both eDNA and water, is most likely greater and thus more visible during the winter base-flow conditions (Zhang et al., 2018), which were omitted from our study.

\subsection{Identification of upstream water contribution}

From a hydrologist's point of view, we hoped eDNA would reveal where water had flowed before emerging as surface water.

5 We tested this by comparing DNA from potential sources (tributaries and springs) with that of the main channel. There was a reasonably high level of recovery in the main channel, 77-79\%, in terms of ZOTUs, and a level, though minimal, of specificity to either springs or tributaries (14-33\%, respectively). DNA, synthetic (Foppen et al., 2013) or natural stream bacterioplankton (Crump et al., 2007), has been found to be useful for observing advection and dispersion, but is questionably useful for tracing mass exchange such as surface transient storage and hyporheic exchange or dilution. In the case of our study site, a quantitative calculation would require validation with additional flow assessments to determine contributions of various springs and tributaries to the main channel.

As an exploratory thought experiment, we decomposed the water from the main channel to the two origins, based on detected eDNA traces. To do so, we make the following assumptions of 1) that the percent of the total ZOTUs found in water from the main channel that were also found in either springs or tributaries reflect the water flow from those channel types, 2) that the rarefied number of ZOTUs equally represented present ZOTUs, 3) that each of those ZOTUs is composed of a similar number of species with a normally distributed number of particles, and 4) that we can interpolate linearly to compute contributions between sampled days. Because the volume of water that we sampled was consistent, we can estimate that there was $14 \%$ and $50 \%$ from springs and tributaries, respectively over the sampled season (Fig. 8). This means that of the total of almost $13.5 \mathrm{~m}^{3}$ that flowed through the outlet in $2017,3.6 \mathrm{~m}^{3}$ flowed before or after the eDNA sampling period. But of the $9.9 \mathrm{~m}^{3} \mathrm{during}$ the eDNA sampling and $5 \mathrm{~m}^{3}$ were from the three sampled or similar tributaries and $1.4 \mathrm{~m}^{3}$ were from the three sampled or similar springs. The remaining $3.6 \mathrm{~m}^{3}$ during the sampling period must be from other source types or upstream. Our decomposition of the hydrograph is based on eDNA particle flow between sources and the main channel. Most hydrologic models base hydrograph decomposition on source area, runoff process, or input magnitudes without a validation method (Weiler et al., 2018). Our thought experiment regarding a eDNA basis for hydrograph decomposition can now be compared to models with the same goal.

\section{5 eDNA is a tracer for the integrated dimensions of hydrologic connectivity}

Our results demonstrate that eDNA has the potential to be used as a metric that integrates the definition of connectivity from different disciplines. As its presence is first determined by the movement of biological organisms, ecological connectivity, or the existence of paths or corridors accessible to the movement of biological organisms (Pringle, 2003; Bracken and Croke, 2007). eDNA presence later indicates transport directly by water or contact between water, hydrologic connectivity, or the efficiency at which water moves from a point to a downstream point (Bracken et al., 2013). And finally, it indicates connectivity of sediment because eDNA is bound and further transported, or geomorphic connectivity (Wohl et al., 2019). Additionally the the presence of the eDNA captures the four dimensions of hydrologic connectivity (see Fig. 7). Hydrologic connectivity, which is 
the medium of the other two definitions of connectivity, is almost always downstream but can take place as exchanges laterally (with the banks), longitudinally (through the network), into the hyporheic zone or groundwater, and evolve temporally (Ward, 1989). Connectivity has significant implications for flood generation, sediment production, and aquatic biodiversity among other management goals (Altermatt, 2013; Nadeau and Rains, 2007; Lange et al., 2018), however its usefulness of a concept

5 is limited by a lack of coherence between all of its various definitions (Wohl et al., 2019). Further research on the connectivity indicated by eDNA is perhaps the solution to an metric that crosses disciplines and dimensions.

\subsection{Recommendations and future steps}

eDNA appears to offer high potential as a hydrologic tracer of flow path connectivity, with high detectability, similar to the utility already demonstrated by synthetic DNA for hydrologic tracing (Foppen et al., 2011; Dahlke et al., 2015). Future studies on the use of eDNA as a hydrologic tracer could also gain from more targeted sampling campaigns in terms of hydrologic conditions, including systematic sampling of discharge recession periods or sampling before and after high flow events generated by different hydrologic processes (e.g. high intensity precipitation events, snow melt-induced floods, glacial melt).

Compared to a synthetic tracer, the metabarcoding approach exposes an enormous quantity of information contained in the DNA that opens the door for machine learning that does not account for physical processes (Good et al., 2018). On the other hand, it is quite challenging to identify individual species which would allow for a physical interpretation of the individual flow paths based on individual distributions and habitat preferences (Carraro et al., 2018). Although the construction of a complete species inventory was not feasible, the next step for using natural occurring eDNA as hydrologic tracers is to identify for example key biota characteristic of glacier melt, permafrost, hyporheic zones, and swift channels. These biota can then be used as tracers for specific water source contributions.

In addition, our results expose the complexity of using a metabarcoding approach for Alpine biodiversity assessments. We recommend that future assessments of richness in Alpine stream networks base their sampling on two aspects, depending on their goals. If the goal is to detect the maximum diversity (i.e., a comparison of the diversity in multiple basins), then the detected diversity should be maximized with a single sampling campaign per stream network taken just after a rain or snow-melt event. Alternatively, if the goal is to detect habitat-specific diversity, then sampling after an event resulting in high $d q / d t$ would not be recommended. In this case, the various habitats, or water sources, should be sampled when the environment is the most stable. Similarly, it is possible that E.C. could be used to guide sampling decisions to target specific flow conditions. Finally, future sampling campaigns should have a clear design to answer specific questions about one or all connectivity dimensions and how eDNA of specific species reflect the hydrologic, geomorphic, versus the ecologic connectivity.

\section{Conclusions}

Our study is a first assessment of the spatial and temporal heterogeneity of eDNA in an Alpine stream system and its potential for hydrologic flow path tracing. Our results give first important insights into the complementarity of eDNA and classically used hydrologic tracers (electrical conductivity, stable isotopes of water, water temperature). Our method of metabarcoding of 
water samples for genetic diversity lays the foundation for an interpretation of the eDNA composition detected at the outlet of a catchment based on a physical understanding of the hydrologic network.

A key result is that discharge variations, $d q / d t$ strongly affect detected eDNA diversity, as reflected in richness, in non-spring habitats, with the highest richness detected in small tributaries compared to the larger main channel. We saw that eDNA as 5 a tracer provided more information about origin, flow, and upstream contribution than the non-biological variables alone in providing a specific identity according to the characteristic sources of spring, tributary, and main channel. Furthermore, spring habitat diversity had a dependence on E.C., suggesting that the underlying governing physical process was the amount of exchange with the subsurface environment. Downstream eDNA composition reflected upstream contributions from springs and tributaries and can be used to to be a symbolic decomposition of the hydrograph. Further work should quantify the individual species contributions, and thus provide the basis for a mass balance, and another level of validation. We conclude that eDNA richness increases when the stream network expands, when there is more over-bank flow, and when the hydrologic connectivity in the hyporheic zone is greater; accordingly, eDNA shows high potential as a tracer for the connectivity of hydrologic flow paths.

Future work on the use of eDNA for hydrologic flow path tracing would benefit from a more quantitative sampling approach and target sampling around events and locations of high hydrologic interest. In particular, observations can focus on situations when there is no current consistent tracer available, such as glacier melt events. Traditional methods to assess biological, sediment, and hydrologic connectivity should be used alongside eDNA monitoring. A further understanding of the implications of heterogeneity seasonally, diurnal, and spatially will also provide new insights into the use of eDNA for biodiversity assessments in highly dynamic hydrologic systems.

Data availability. Sequencing data will be publicly available on European Nucleotide Archive and isotope and related data will be published on Zenodo after acceptance.

Author contributions. EM, FA, AS, AL, BS, and NC conceived the ideas and designed methodology; EM, AS, JCW, AL, and NC collected the data; EM and NC analyzed the data; EM and NC led the writing of the manuscript; AL contributed Fig. 7. All authors contributed critically to the drafts and gave final approval for publication. FA and BS secured funding.

Competing interests. Author BS is a member of the editorial board of the journal, but otherwise there are no competing interests present that the authors are aware of.

Acknowledgements. Data analyzed in this paper were generated in collaboration with the Genetic Diversity Centre (GDC), ETH Zurich. Field work and infrastructure was supported by the Institute of Earth Surface Dynamics at the University of Lausanne, in particular by 
https://doi.org/10.5194/hess-2019-551

Preprint. Discussion started: 23 October 2019

(C) Author(s) 2019. CC BY 4.0 License.

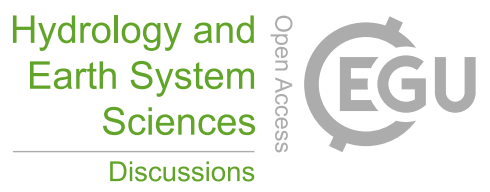

(c) (1)

Discussions

all members of the catchment hydrology group for field and laboratory work, and by Dr. Torsten Vennemann and Dr. Jasquelin Peña for laboratory equipment and space. We would like to thank Samuel Hürlemann and Marco Thali for help in the lab. Funding is from the Swiss National Science Foundation Grants No PP00P3_179089, 31003A_173074 (to FA), PP00P2_157611 (to BS), the Velux Foundation, and the Chuard Schmid Foundation (to BS). 


\section{References}

Abbott, B. W., Baranov, V., Mendoza-Lera, C., Nikolakopoulou, M., Harjung, A., Kolbe, T., Balasubramanian, M. N., Vaessen, T. N., Ciocca, F., Campeau, A., et al.: Using multi-tracer inference to move beyond single-catchment ecohydrology, Earth-Science Reviews, 160, 19-42, 2016.

5 Altermatt, F.: Diversity in riverine metacommunities: a network perspective, Aquatic Ecology, 47, 365-377, 2013.

Aschwanden, H. and Weingartner, R.: Abschätzungen im Mittelwasserbereich, Beitr. Geol. Schweiz Hydrol, 33, 101-139, 1985.

Barnes, M. A. and Turner, C. R.: The ecology of environmental DNA and implications for conservation genetics, Conservation Genetics, 17, $1-17,2016$.

Bates, D., Sarkar, D., Bates, M. D., and Matrix, L.: The lme4 package, R package version, 2, 74, 2007.

Beentjes, K. K., Speksnijder, A. G., Schilthuizen, M., Hoogeveen, M., and van der Hoorn, B. B.: The effects of spatial and temporal replicate sampling on eDNA metabarcoding, PeerJ, 7, e7335, 2019.

Belle, C. C., Stoeckle, B. C., and Geist, J.: Taxonomic and geographical representation of freshwater environmental DNA research in aquatic conservation, Aquatic Conservation: Marine and Freshwater Ecosystems, 2019.

Beria, H., Larsen, J. R., Ceperley, N. C., Michelon, A., Vennemann, T., and Schaefli, B.: Understanding snow hydrological processes through the lens of stable water isotopes, Wiley Interdisciplinary Reviews: Water, 5, e1311, https://onlinelibrary.wiley.com/doi/abs/10.1002/wat2. $1311,2018$.

Bista, I., Carvalho, G. R., Walsh, K., Seymour, M., Hajibabaei, M., Lallias, D., Christmas, M., and Creer, S.: Annual time-series analysis of aqueous eDNA reveals ecologically relevant dynamics of lake ecosystem biodiversity, Nature communications, 8, $14087,2017$.

Blume, T. and Van Meerveld, H.: From hillslope to stream: methods to investigate subsurface connectivity, Wiley Interdisciplinary Reviews: Water, 2, 177-198, 2015.

Bohmann, K., Evans, A., Gilbert, M. T. P., Carvalho, G. R., Creer, S., Knapp, M., Douglas, W. Y., and De Bruyn, M.: Environmental DNA for wildlife biology and biodiversity monitoring, Trends in ecology \& evolution, 29, 358-367, 2014.

Bracken, L., Wainwright, J., Ali, G., Tetzlaff, D., Smith, M., Reaney, S., and Roy, A.: Concepts of hydrological connectivity: research approaches, pathways and future agendas, Earth-Science Reviews, 119, 17-34, 2013.

Bracken, L. J. and Croke, J.: The concept of hydrological connectivity and its contribution to understanding runoff-dominated geomorphic systems, Hydrological Processes: An International Journal, 21, 1749-1763, 2007.

Brown, L., Hannah, D., and Milner, A.: Alpine stream habitat classification: an alternative approach incorporating the role of dynamic water source contributions, Arctic, Antarctic, and Alpine Research, 35, 313-322, 2003.

Carraro, L., Hartikainen, H., Jokela, J., Bertuzzo, E., and Rinaldo, A.: Estimating species distribution and abundance in river networks using environmental DNA, Proceedings of the National Academy of Sciences, 115, 11 724-11 729, https://doi.org/10.1073/pnas.1813843115, https://www.pnas.org/content/115/46/11724, 2018.

Ceperley, N., Michelon, A., Escoffier, N., Mayoraz, G., Boix Canadell, M., Horgby, A., Hammer, F., Antoniazza, G., Schaefli, B., Lane, S., Rickenmann, D., and Boss, S.: Salt gauging and stage-discharge curve, Avançon de Nant, outlet Vallon de Nant catchment, https://doi.org/10.5281/zenodo.1154798, https://doi.org/10.5281/zenodo.1154798, 2018.

35 Chorley, R. J.: The hillslope hydrological cycle, John Wiley, Chichester, 1978.

Cochand, M., Christe, P., Ornstein, P., and Hunkeler, D.: Groundwater Storage in High Alpine Catchments and its Contribution to Streamflow, Water Resources Research, 2019. 
Comola, F., Schaefli, B., Rinaldo, A., and Lehning, M.: Thermodynamics in the hydrologic response: Travel time formulation and application to Alpine catchments, Water Resources Research, 51, 1671-1687, 2015.

Constantz, J.: Interaction between stream temperature, streamflow, and groundwater exchanges in alpine streams, Water resources research, 34, 1609-1615, 1998.

5 Coplen, T. B.: Reporting of stable hydrogen, carbon, and oxygen isotopic abundances (technical report), Pure and Applied Chemistry, 66, 273-276, 1994.

Coxe, S., West, S. G., and Aiken, L. S.: The analysis of count data: A gentle introduction to Poisson regression and its alternatives, Journal of personality assessment, 91, 121-136, 2009.

Crawley, M. J.: The R book, John Wiley \& Sons, 2012.

Crump, B. C., Adams, H. E., Hobbie, J. E., and Kling, G. W.: Biogeography of bacterioplankton in lakes and streams of an arctic tundra catchment, Ecology, 88, 1365-1378, 2007.

Dahlke, H. E., Williamson, A. G., Georgakakos, C., Leung, S., Sharma, A. N., Lyon, S. W., and Walter, M. T.: Using concurrent DNA tracer injections to infer glacial flow pathways, Hydrological Processes, 29, 5257-5274, 2015.

Deiner, K. and Altermatt, F.: Transport distance of invertebrate environmental DNA in a natural river, PloS one, 9, e88 786, 2014.

Deiner, K., Walser, J.-C., Mächler, E., and Altermatt, F.: Choice of capture and extraction methods affect detection of freshwater biodiversity from environmental DNA, Biological Conservation, 183, 53-63, 2015.

Edgar, R. C.: UNOISE2: improved error-correction for Illumina 16S and ITS amplicon sequencing, BioRxiv, p. $081257,2016$.

Evans, N. T., Li, Y., Renshaw, M. A., Olds, B. P., Deiner, K., Turner, C. R., Jerde, C. L., Lodge, D. M., Lamberti, G. A., and Pfrender, M. E.: Fish community assessment with eDNA metabarcoding: effects of sampling design and bioinformatic filtering, Canadian Journal of Fisheries and Aquatic Sciences, 74, 1362-1374, 2017.

Fallot, J.-M.: Sentier didactique pour le Vallon de Nant, partie Climatique, Tech. rep., University of Lausanne, Geoguide, http://igd.unil.ch/ geoguide/fr/, 2013.

Foppen, J. W., Orup, C., Adell, R., Poulalion, V., and Uhlenbrook, S.: Using multiple artificial DNA tracers in hydrology, Hydrological Processes, 25, 3101-3106, 2011.

Foppen, J. W., Seopa, J., Bakobie, N., and Bogaard, T.: Development of a methodology for the application of synthetic DNA in stream tracer injection experiments, Water resources research, 49, 5369-5380, 2013.

Freitag, A.: Note sur quelques insectes observés dans le Vallon de Nant (Bex, Alpes vaudoises), Mémoire de la Société vaudoise des Sciences naturelles, 23, 171-178, 2009.

Füreder, L., Vacha, C., Amprosi, K., Bühler, S., Hansen, C., and Moritz, C.: Reference conditions of alpine streams: physical habitat and ecology, Water, Air and Soil Pollution: Focus, 2, 275-294, 2002.

Gattolliat, J.-L., Knispel, S., Lods-Crozet, B., Lubini, V., and Sartori, M.: Macroinvertébrés aquatiques du Vallon de Nant (Bex, Alpes vaudoises), Biodiversité du Vallon de Nant. Mémoire de la Société vaudoise de Sciences naturelles, 23, 129-144, 2009.

Geller, J., Meyer, C., Parker, M., and Hawk, H.: Redesign of PCR primers for mitochondrial cytochrome c oxidase subunit I for marine invertebrates and application in all-taxa biotic surveys, Molecular ecology resources, 13, 851-861, 2013.

GLAMOS: The Swiss Glaciers 1881-2016/17, Glaciological Reports No 1-138, Yearbooks of the Cryospheric Commission of the Swiss Academy of Sciences (SCNAT), published since 1964 by, VAW / ETH Zurich, doi:10.18752/glrep_series, 1881-2018.

Godsey, S. and Kirchner, J.: Dynamic, discontinuous stream networks: hydrologically driven variations in active drainage density, flowing channels and stream order, Hydrological Processes, 2014. 
Good, S., URycki, D., and Crump, B.: Predicting Hydrologic Function With Aquatic Gene Fragments, Water Resources Research, 54, 2424$2435,2018$.

Grabherr, G.: Biodiversity in the high ranges of the Alps: ethnobotanical and climate change perspectives, Global Environmental Change, 19, 167-172, 2009.

5 Hebert, P. D., Ratnasingham, S., and de Waard, J. R.: Barcoding animal life: cytochrome c oxidase subunit 1 divergences among closely related species, Proceedings of the Royal Society of London. Series B: Biological Sciences, 270, S96-S99, 2003.

Helfer, V. and Monney, J.-C.: Batraciens et reptiles du Vallon de Nant (Bex, Alpes vaudoises)-Premier recensement, in: Biodiversité du Vallon de Nant., vol. 23, Mémoire de la société vaudoise des Sciences naturelles, 2009.

Hoehn, E. and Cirpka, O. A.: Assessing hyporheic zone dynamics in two alluvial flood plains of the Southern Alps using water temperature and tracers, Hydrology and Earth System Sciences Discussions, 3, 335-364, https://hal.archives-ouvertes.fr/hal-00298667, 2006.

Ingelrest, F., Barrenetxea, G., Schaefer, G., Vetterli, M., Couach, O., and Parlange, M.: Sensorscope: Application-specific sensor network for environmental monitoring, ACM Transactions on Sensor Networks (TOSN), 6, 17, 2010.

Jacobsen, D., Milner, A. M., Brown, L. E., and Dangles, O.: Biodiversity under threat in glacier-fed river systems, Nature Climate Change, $2,361,2012$.

Khamis, K., Hannah, D., Clarvis, M. H., Brown, L., Castella, E., and Milner, A.: Alpine aquatic ecosystem conservation policy in a changing climate, Environmental Science \& Policy, 43, 39-55, 2014.

Klaus, J. and McDonnell, J.: Hydrograph separation using stable isotopes: Review and evaluation, Journal of Hydrology, $505,2013$.

Kobierska, F., Jonas, T., Kirchner, J. W., and Bernasconi, S. M.: Linking baseflow separation and groundwater storage dynamics in an alpine basin (Dammagletscher, Switzerland), Hydrology and Earth System Sciences, 19, 3681-3693, https://doi.org/10.5194/hess-19-3681-2015, https://www.hydrol-earth-syst-sci.net/19/3681/2015/, 2015.

Körner, C.: Impact of atmospheric changes on high mountain vegetation, in: Mountain environments in changing climates, pp. 149-157, Routledge, 2002.

Kruskal, J. B.: Multidimensional scaling by optimizing goodness of fit to a nonmetric hypothesis, Psychometrika, 29, 1-27, 1964a.

Kruskal, J. B.: Nonmetric multidimensional scaling: a numerical method, Psychometrika, 29, 115-129, 1964 b.

Lan, B., Zhang, D., Yang, Y., He, L., Zhang, X., and Zhong, R.: Diatom-based reconstructions of hydrological variations and the underlying mechanisms during the past 520 years in the central Tianshan Mountains, Journal of Hydrology, https://doi.org/https://doi.org/10.1016/j.jhydrol.2019.06.001, http://www.sciencedirect.com/science/article/pii/S0022169419305414, 2019.

Landwehr, J. and Coplen, T.: Line-conditioned excess: a new method for characterizing stable hydrogen and oxygen isotope ratios in hydrologic systems, in: International conference on isotopes in environmental studies, pp. 132-135, Int. At. Energy Agency Vienna, 2006.

Lange, K., Meier, P., Trautwein, C., Schmid, M., Robinson, C. T., Weber, C., and Brodersen, J.: Basin-scale effects of small hydropower on biodiversity dynamics, Frontiers in Ecology and the Environment, 16, 397-404, 2018.

Leray, M., Yang, J. Y., Meyer, C. P., Mills, S. C., Agudelo, N., Ranwez, V., Boehm, J. T., and Machida, R. J.: A new versatile primer set targeting a short fragment of the mitochondrial COI region for metabarcoding metazoan diversity: application for characterizing coral reef fish gut contents, Frontiers in zoology, 10, 34, 2013.

Lozupone, C. and Knight, R.: UniFrac: a new phylogenetic method for comparing microbial communities, Appl. Environ. Microbiol., 71, 8228-8235, 2005. 
Lyon, S. W., Ploum, S. W., van der Velde, Y., Rocher-Ros, G., Mörth, C.-M., and Giesler, R.: Lessons learned from monitoring the stable water isotopic variability in precipitation and streamflow across a snow-dominated subarctic catchment, Arctic, Antarctic, and Alpine Research, 50, e1454 778, 2018.

Mächler, E., Deiner, K., Spahn, F., and Altermatt, F.: Fishing in the water: effect of sampled water volume on environmental DNA-based detection of macroinvertebrates, Environmental science \& technology, 50, 305-312, 2015.

Mächler, E., Osathanunkul, M., and Altermatt, F.: Shedding light on eDNA: neither natural levels of UV radiation nor the presence of a filter feeder affect eDNA-based detection of aquatic organisms, PLoS One, 13, e0195 529, 2018.

Malard, F., Tockner, K., and Ward, J.: Shifting dominance of subcatchment water sources and flow paths in a glacial floodplain, Val Roseg, Switzerland, Arctic, Antarctic, and Alpine Research, 31, 135-150, 1999.

Malard, F., Tockner, K., and Ward, J.: Physico-chemical heterogeneity in a glacial riverscape, Landscape Ecology, 15, 679-695, 2000.

Marchesi, P., Lugrin, R., Roch, J.-C., and Vogel, P.: Mammifères terrestres du Vallon de Nant(Bex, Alpes vaudoises), in: Biodiversité du Vallon de Nant., vol. 23, pp. 203-216, Mémoire de la société vaudoise des Sciences naturelles, 2009.

McDonnell, J. J., Sivapalan, M., Vache, K., Dunn, S., Grant, G., Haggerty, R., Hinz, C., Hooper, R., Kirchner, J., Roderick, M. L., Selker, J., and Weiler, M.: Moving beyond heterogeneity and process complexity: A new vision for watershed hydrology, Water Resources Research, 43, n/a-n/a, https://doi.org/10.1029/2006WR005467, http://doi.wiley.com/10.1029/2006WR005467http://www.agu.org/pubs/ crossref/2007/2006WR005467.shtml, 2007.

McGuire, K. J. and McDonnell, J. J.: Tracer advances in catchment hydrology, Hydrological Processes, 29, 5135-5138, 2015.

McMurdie, P. J. and Holmes, S.: phyloseq: an R package for reproducible interactive analysis and graphics of microbiome census data, PloS one, 8, e61217, 2013.

McNew, C. P., Wang, C., Walter, M. T., and Dahlke, H. E.: Fabrication, detection, and analysis of DNA-labeled PLGA particles for environmental transport studies, Journal of colloid and interface science, 526, 207-219, 2018.

MeteoSwiss: Documentation of MeteoSwiss Grid-Data Products: Daily Precipitation (final analysis): RhiresD, Tech. rep., MeteoSwiss, 2011. MeteoSwiss: Automatic monitoring network SWISSMETNET, https://www.meteoswiss.admin.ch/home/ measurement-and-forecasting-systems/land-based-stations/automatisches-messnetz.html, 2019.

Michelon, A.: Weather dataset from Vallon de Nant, Switzerland, until July 2017, https://doi.org/10.5281/zenodo.1042473, https://doi.org/ 10.5281/zenodo.1042473, This will be expanded to include more data (hydrological, \& meteorological), and more complete metadata., 2017.

Michelon, A., Ceperley, N., Beria, H., Larsen, J., and Schaefli, B.: Quantification of snowmelt processes in a high Alpine catchment from hydrographs and satellite images and stable water isotopes., in: General Assembly, European Geosciences Union, Vienna, Austria, 2018.

Milner, A. M. and Petts, G. E.: Glacial rivers: physical habitat and ecology, Freshwater Biology, 32, 295-307, https://doi.org/10.1111/j.13652427.1994.tb01127.x, https://onlinelibrary.wiley.com/doi/abs/10.1111/j.1365-2427.1994.tb01127.x, 1994.

Morard, E.: Oiseaux du Vallon de Nant (Bex, Alpes vaudoises), in: Biodiversité du Vallon de Nant., vol. 23, Mémoire de la société vaudoise des Sciences naturelles, 2009.

Mosquera, G., Segura, C., and Crespo, P.: Flow Partitioning Modelling Using High-Resolution Isotopic and Electrical Conductivity Data, Water, 10, 904, 2018.

Nadeau, T.-L. and Rains, M. C.: Hydrological connectivity between headwater streams and downstream waters: how science can inform policy 1, JAWRA Journal of the American Water Resources Association, 43, 118-133, 2007. 
Nolin, A. W.: Perspectives on climate change, mountain hydrology, and water resources in the Oregon Cascades, USA, Mountain Research and Development, 32, 2012.

Oksanen, J., Kindt, R., Legendre, P., O’Hara, B., Stevens, M. H. H., Oksanen, M. J., and Suggests, M.: The vegan package, Community ecology package, 10, 631-637, 2007.

5 Penna, D., Engel, M., Mao, L., Dell'Agnese, A., Bertoldi, G., and Comiti, F.: Tracer-based analysis of spatial and temporal variations of water sources in a glacierized catchment, Hydrology and Earth System Sciences, 18, 5271-5288, https://doi.org/10.5194/hess-18-5271-2014, 2014.

Penna, D., Hopp, L., Scandellari, F., Allen, S. T., Benettin, P., Beyer, M., Geris, J., Klaus, J., Marshall, J. D., Schwendenmann, L., Volkmann, T. H. M., von Freyberg, J., Amin, A., Ceperley, N., Engel, M., Frentress, J., Giambastiani, Y., McDonnell, J. J., Zuecco, G., Llorens, P., Siegwolf, R. T. W., Dawson, T. E., and Kirchner, J. W.: Ideas and perspectives: Tracing terrestrial ecosystem water fluxes using hydrogen and oxygen stable isotopes - challenges and opportunities from an interdisciplinary perspective, Biogeosciences, 15, 63996415, https://doi.org/10.5194/bg-15-6399-2018, https://www.biogeosciences.net/15/6399/2018/, 2018.

Pfister, L., McDonnell, J. J., Wrede, S., Hlúbiková, D., Matgen, P., Fenicia, F., Ector, L., and Hoffmann, L.: The rivers are alive: on the potential for diatoms as a tracer of water source and hydrological connectivity, Hydrological Processes: An International Journal, 23, 2841-2845, 2009.

Pringle, C.: What is hydrologic connectivity and why is it ecologically important?, Hydrological Processes, 17, 2685-2689, 2003.

R Core Team: R: A Language and Environment for Statistical Computing, R Foundation for Statistical Computing, Vienna, Austria, https: //www.R-project.org/, 2018.

Savio, D., Sinclair, L., Ijaz, U. Z., Parajka, J., Reischer, G. H., Stadler, P., Blaschke, A. P., Blöschl, G., Mach, R. L., Kirschner, A. K., et al.: Bacterial diversity along a $2600 \mathrm{~km}$ river continuum, Environmental microbiology, 17, 4994-5007, 2015.

Selker, J. S., Thévenaz, L., Huwald, H., Mallet, A., Luxemburg, W., Van De Giesen, N., Stejskal, M., Zeman, J., Westhoff, M., and Parlange, M. B.: Distributed fiber-optic temperature sensing for hydrologic systems, Water Resources Research, 42, 2006.

Seymour, M., Durance, I., Cosby, B. J., Ransom-Jones, E., Deiner, K., Ormerod, S. J., Colbourne, J. K., Wilgar, G., Carvalho, G. R., de Bruyn, M., et al.: Acidity promotes degradation of multi-species environmental DNA in lotic mesocosms, Communications biology, 1, 4, 2018.

Simberloff, D.: Use of rarefaction and related methods in ecology, in: Biological data in water pollution assessment: quantitative and statistical analyses, ASTM International, 1978.

Smith, B. P., Hannah, D. M., Gurnell, A. M., and Petts, G. E.: A hydrogeomorphological context for ecological research on alpine glacial rivers, Freshwater Biology, 46, 1579-1596, 2001.

Strickler, K. M., Fremier, A. K., and Goldberg, C. S.: Quantifying effects of UV-B, temperature, and pH on eDNA degradation in aquatic microcosms, Biological Conservation, 183, 85-92, 2015.

Tetzlaff, D., Buttle, J., Carey, S. K., McGuire, K., Laudon, H., and Soulsby, C.: Tracer-based assessment of flow paths, storage and runoff generation in northern catchments: a review, Hydrological Processes, 29, 3475-3490, https://doi.org/10.1002/hyp.10412, 2015.

Thalinger, B., Sint, D., Zeisler, C., Kirschner, D., Traugott, M., Moritz, C., and Schwarzenberger, R.: Quantifizierung von Fischbeständen mittels eDNA in alpinen Fließgewässern, WASSERWIRTSCHAFT-STUTTGART-, 108, 30-34, 2018.

Thornton, J. M., Mariethoz, G., and Brunner, P.: A 3D geological model of a structurally complex Alpine region as a basis for interdisciplinary research, Scientific Data, 5, 180 238, https://doi.org/10.1038/sdata.2018.238, http://dx.doi.org/10.1038/sdata.2018.238, 2018.

Ushio, M., Fukuda, H., Inoue, T., Makoto, K., Kishida, O., Sato, K., Murata, K., Nikaido, M., Sado, T., Sato, Y., et al.: Environmental DNA enables detection of terrestrial mammals from forest pond water, Molecular Ecology Resources, 17, e63-e75, 2017. 
Valentini, A., Taberlet, P., Miaud, C., Civade, R., Herder, J., Thomsen, P. F., Bellemain, E., Besnard, A., Coissac, E., Boyer, F., et al.: Next-generation monitoring of aquatic biodiversity using environmental DNA metabarcoding, Molecular Ecology, 25, 929-942, 2016.

van Meerveld, H. J. I., Kirchner, J. W., Vis, M. J. P., Assendelft, R. S., and Seibert, J.: Expansion and contraction of the flowing stream network changes hillslope flowpath lengths and the shape of the travel time distribution, Hydrology and Earth System Sciences Discussions, 2019, 1-18, https://doi.org/10.5194/hess-2019-218, https://www.hydrol-earth-syst-sci-discuss.net/hess-2019-218/, 2019.

Viviroli, D., Dürr, H. H., Messerli, B., Meybeck, M., and Weingartner, R.: Mountains of the world, water towers for humanity: Typology, mapping, and global significance, Water Resources Research, 43, 1-13, https://doi.org/10.1029/2006WR005653, 2007.

Wang, C., Parlange, J.-Y., Rasmussen, E., Wang, X., Chen, M., Dahlke, H., and Walter, M.: Modeling the release of Escherichia coli from soil into overland flow under raindrop impact, Advances in water resources, 106, 144-153, 2017.

Ward, J.: The four-dimensional nature of lotic ecosystems, Journal of the North American Benthological Society, 8, 2-8, 1989.

Ward, J.: Ecology of alpine streams, Freshwater biology, 32, 277-294, 1994.

Weiler, M., Seibert, J., and Stahl, K.: Magic components-why quantifying rain, snowmelt, and icemelt in river discharge is not easy, Hydrological processes, 32, 160-166, 2018.

Westhoff, M. C., Savenije, H. H. G., Luxemburg, W. M. J. ., Stelling, G. S., Van De Giesen, N. C., Selker, J. S., Pfister, L., and Uhlenbrook, S.: A distributed stream temperature model using high resolution temperature observations, Hydrology and Earth System Sciences Discussions, 11, 1469-1480, https://hal.archives-ouvertes.fr/hal-00305086, 2007.

Wilhelm, L., Singer, G. A., Fasching, C., Battin, T. J., and Besemer, K.: Microbial biodiversity in glacier-fed streams, The ISME journal, 7 , $1651,2013$.

Williams, M. W., Knauf, M., Caine, N., Liu, F., and Verplanck, P. L.: Geochemistry and source waters of rock glacier outflow, Colorado Front Range, Permafrost and Periglacial Processes, 17, 13-33, 2006.

Williams, M. W., Siebold, C., and Chowanski, K.: Storage and Release of Solutes from a subalpine Seasonal Snowpack: Soil and Stream Water Response, Niwot Ridge Colorado, Biogeochemistry, 95, 77-94, 2009.

Wohl, E., Brierley, G., Cadol, D., Coulthard, T. J., Covino, T., Fryirs, K. A., Grant, G., Hilton, R. G., Lane, S. N., Magilligan, F. J., et al.: Connectivity as an emergent property of geomorphic systems, Earth Surface Processes and Landforms, 44, 4-26, 2019.

Zhang, J., Song, J., Long, Y., Kong, F., Wang, L., Zhang, Y., Li, Q., Wang, Y., and Hui, Y.: Seasonal variability of hyporheic water exchange of the Weihe River in Shaanxi Province, China, Ecological Indicators, 92 , 278 - 287, https://doi.org/https://doi.org/10.1016/j.ecolind.2017.06.039, http://www.sciencedirect.com/science/article/pii/S1470160X17303813, multi-Scale Ecological Indicators for Supporting Sustainable Watershed Management, 2018.

Zuecco, G., Carturan, L., De Blasi, F., Seppi, R., Zanoner, T., Penna, D., Borga, M., Carton, A., and Dalla Fontana, G.: Understanding 


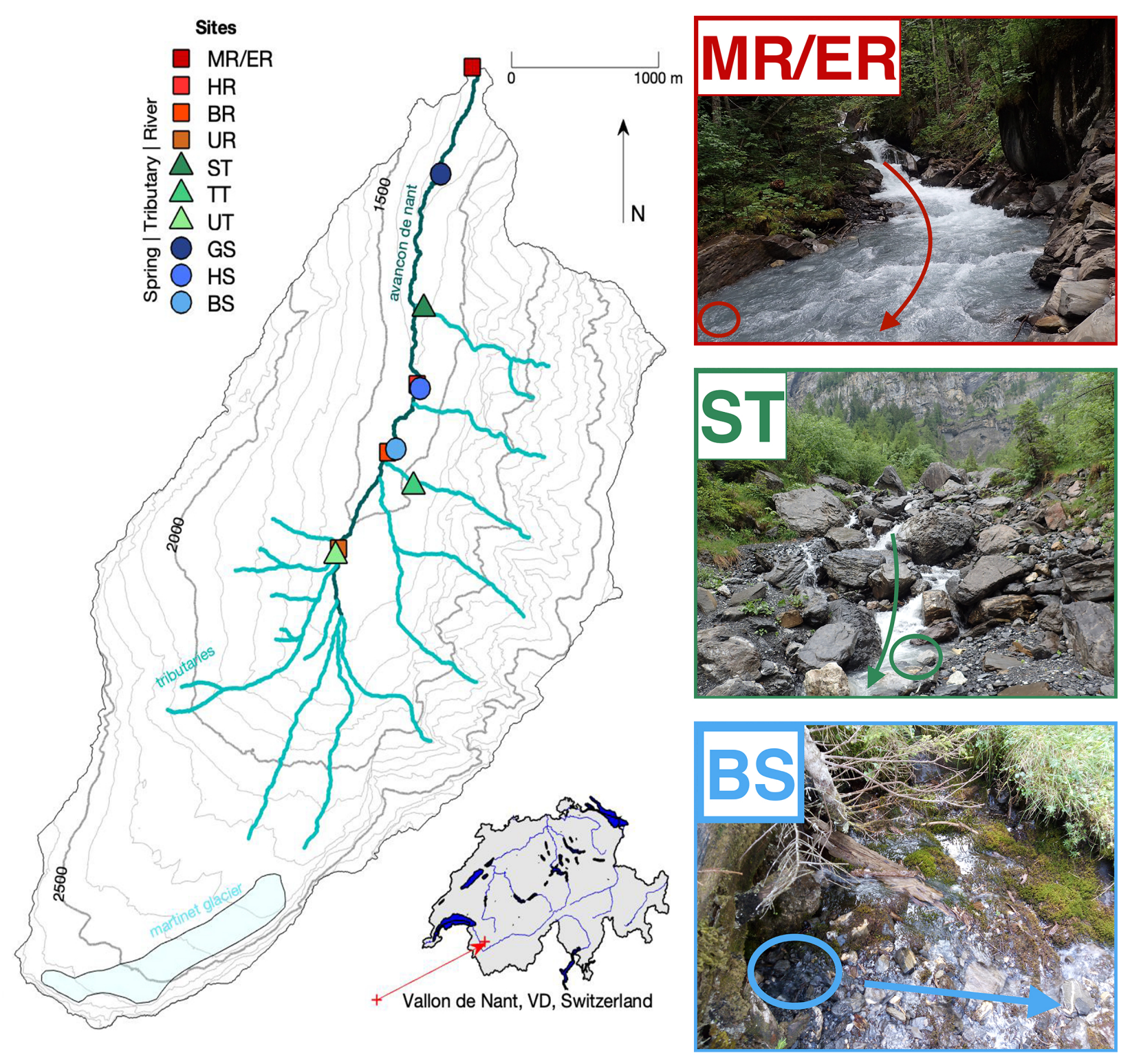

Figure 1. Map of Vallon de Nant showing sampling sites and stream network. Main channel sites are red squares, tributaries by green triangles and springs are represented with blue circles, in all three cases, shading lightens with elevation. The two letter codes are used to identify the sites. The main channel is the Avançon de Nant, which is shown in dark cyan and predominately ephemeral tributaries of various origins are shown in turquoise. The remaining Martinet glacier is shown in light blue. The location of the catchment on an outline of Switzerland with its main hydrologic network is shown to the lower right. On the right are pictures of the main channel (MR/ER, top), a tributary (ST, middle) and a spring (BS, bottom). Colored circles show sampling points and arrows show direction of water flow. 


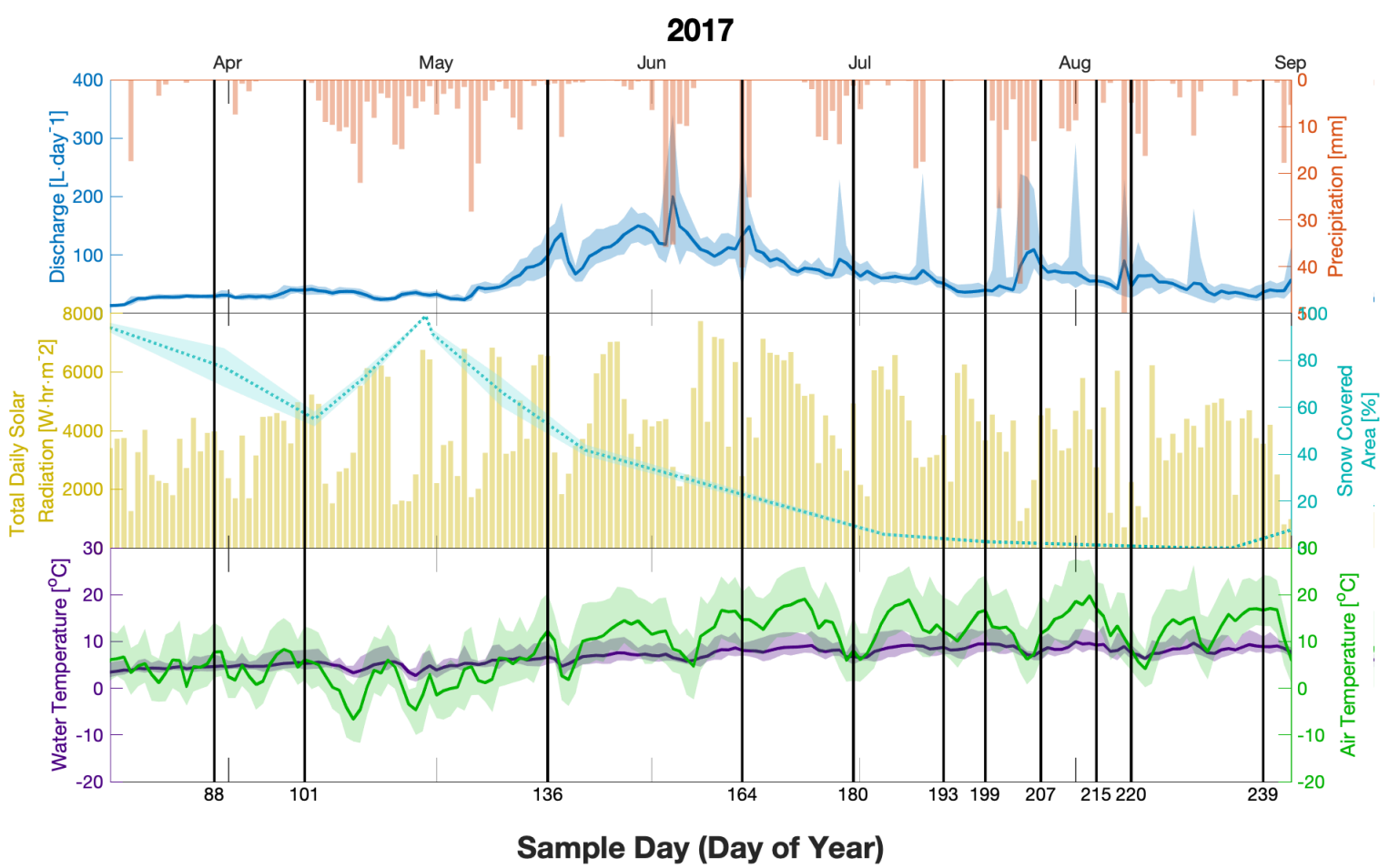

Figure 2. Discharge (blue, upper), precipitation (red upper), total solar radiation (yellow, middle), snow cover area (cyan, middle), water temperature (purple, lower) and air temperature (green, lower) for the sampling season (2017). Meteorological variables are averaged over the catchment area and discharge and water temperature are measured at the outlet (MR/ER). Shaded areas for discharge and temperature show the range of values within a day at the 1 and 4 stations, respectively, and shows the error for snow covered area estimated from satellite data. Sampling days indicated as black vertical lines with the corresponding day of the year on the lower axis. 

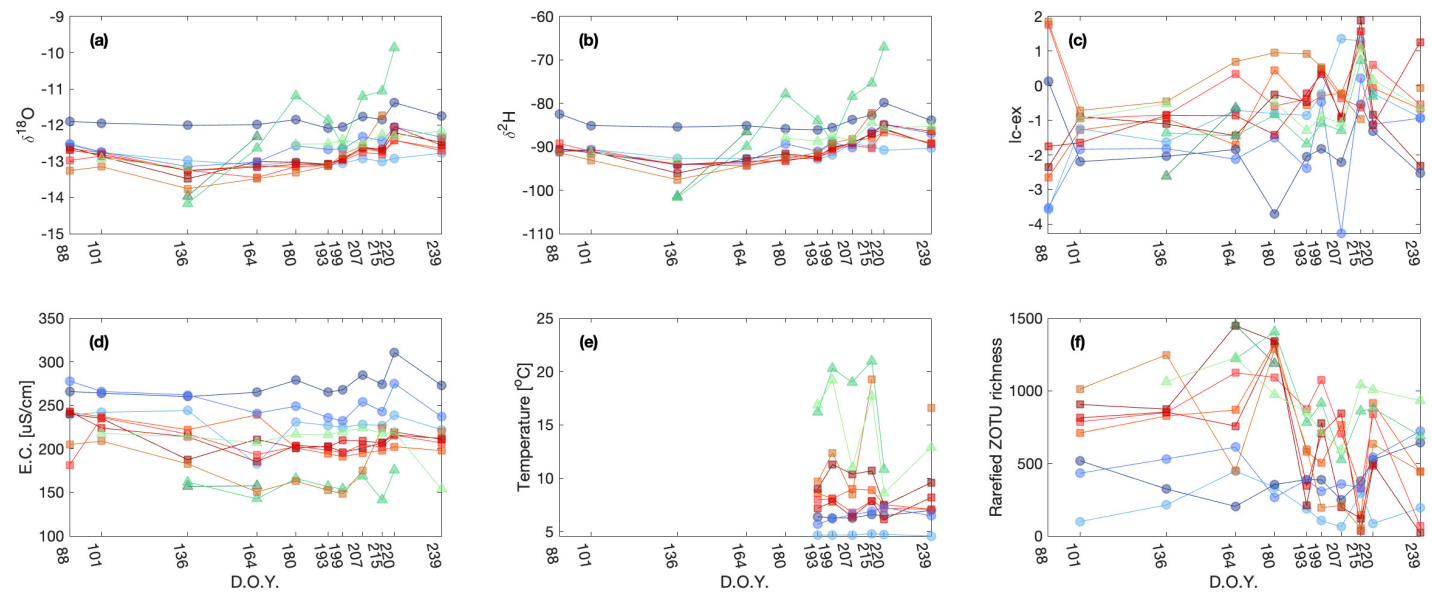

Figure 3. Variation in $\delta^{18} \mathrm{O}(\mathrm{a}), \delta^{2} \mathrm{H}(\mathrm{b})$, lc-ex (c), E.C. (d), temperature (e), and rarefied ZOTU richness (f) for the individual sampling sites over the field season (given as day of the year). The sampling sites in the legend are clustered based on the water source and within the cluster ordered from low to high elevation. The figure legend corresponds exactly to that in Fig. 1 and the x-axis corresponds exactly to that in Fig. 2.

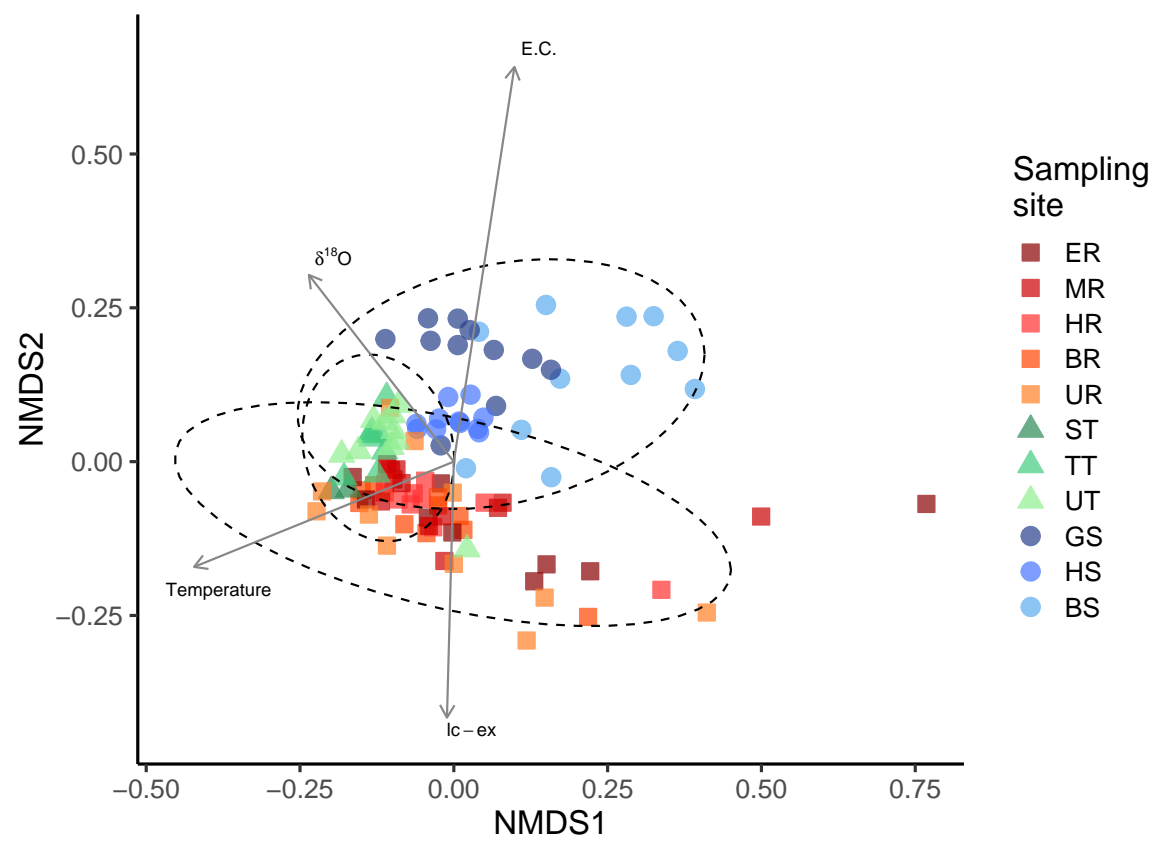

Figure 4. Community composition in the main channel, tributaries and springs. Non-metric multidimensional scaling analysis of communities based on UniFrac dissimilarities (stress $=0.132$, indicating a fair representation of the data in the reduced dimensions). Ellipses represent a $95 \%$ confidence interval. 

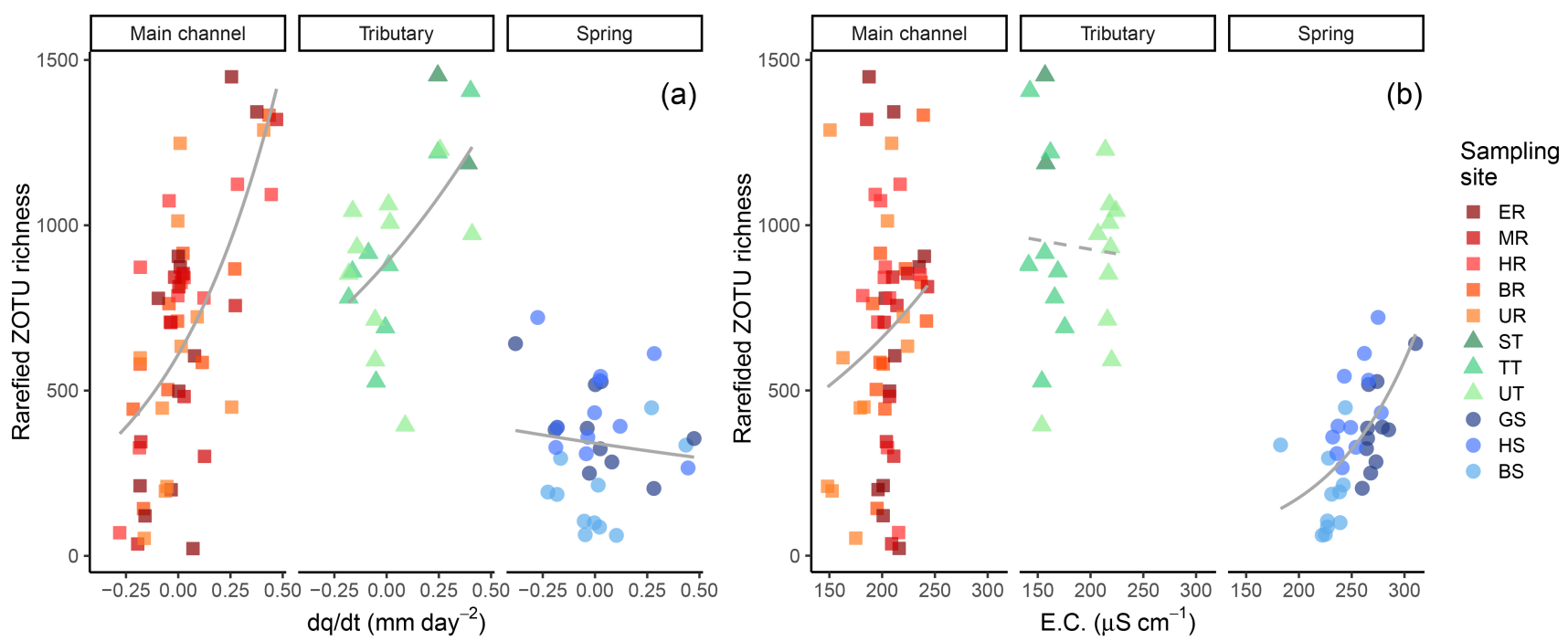

Figure 5. Rarefied ZOTU richness plotted against $d q / d t$ (a) and E.C. (b). The sampling sites in the legend are clustered based on the water source and within the cluster ordered from low to high elevation. Solid lines indicate significant interactions of fixed effects and the dashed line indicates significant relationship of the fixed effects and the response variable only (without observed significant interaction). We plotted smoothing lines based on a GLM function.

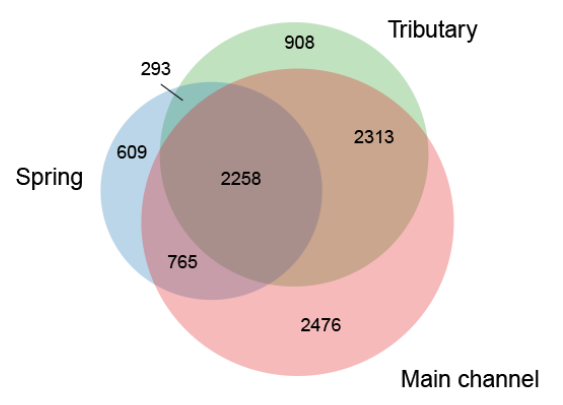

(a)
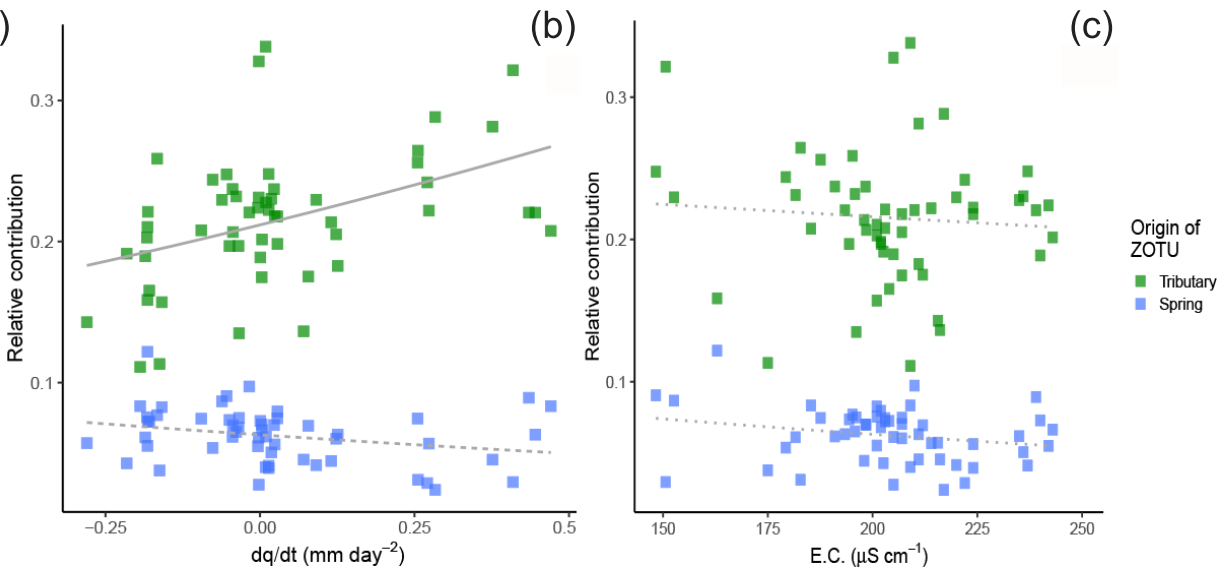

Figure 6. Venn diagram for the three sampled water sources, overlapping areas depict shared ZOTUs between water sources (a). Values indicate the numbers of ZOTUs in the given section and size of the circles are weighted by the number of ZOTUs. Relative contribution of ZOTUs from tributaries (green) or springs (blue) to samples in the main channel against $d q / d t$ (b) and E.C. (c). The solid line indicates significant interactions of fixed effects, the dashed lines indicate significant relationships of both fixed effects and response variable only (without significant interaction) and the dotted line indicates only the significant relationship of one fixed effect. We plotted smoothing lines based on a GLM function. 
https://doi.org/10.5194/hess-2019-551

Preprint. Discussion started: 23 October 2019

(c) Author(s) 2019. CC BY 4.0 License.
Hydrology and
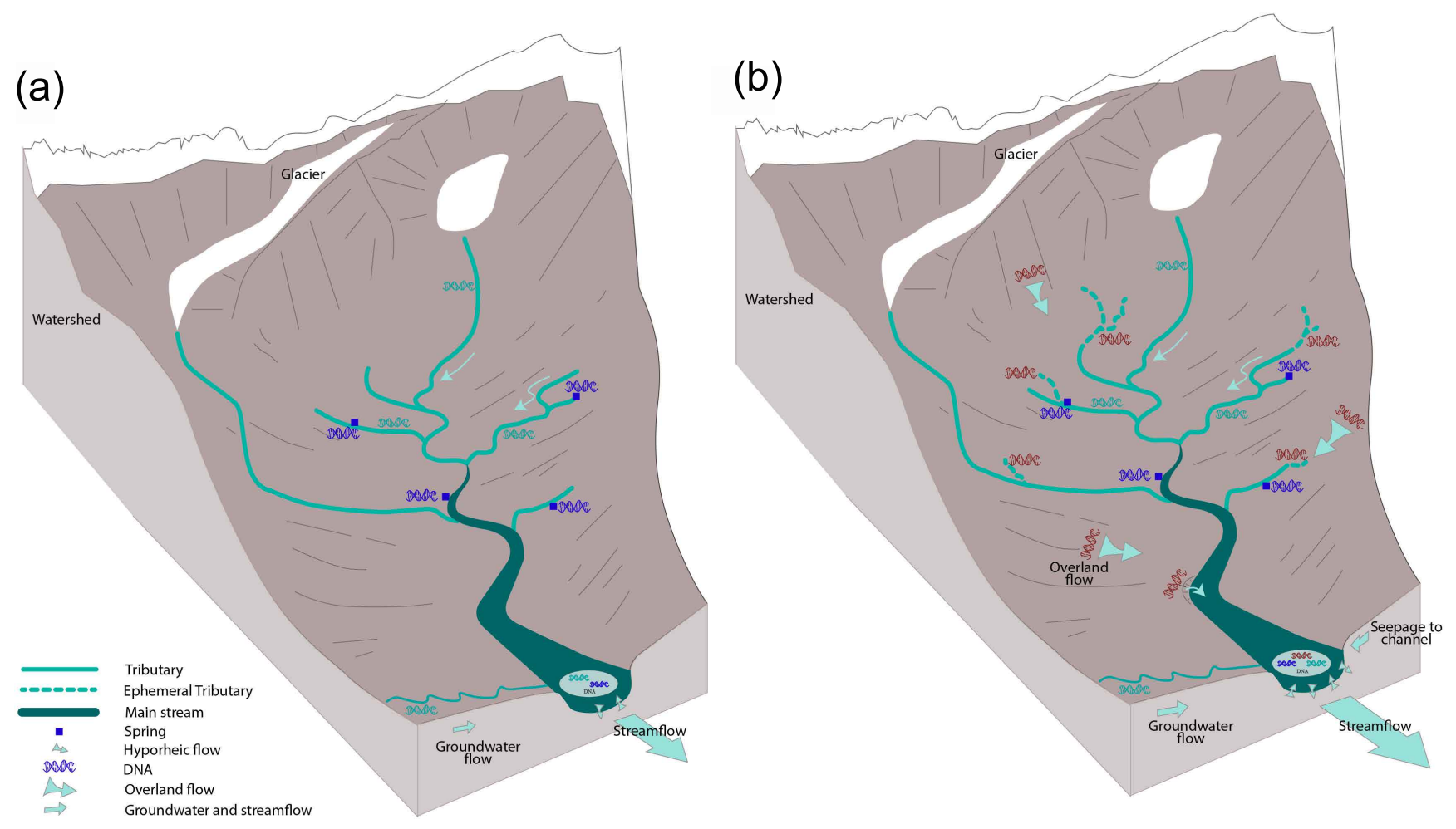

Figure 7. Conceptual flow of relation between $d q / d t$ and eDNA richness in the hydrologic system. When $d q / d t$ negative (a), the limited hydrological connectivity and the limited connectivity between the terrestrial and aquatic habitat leads to a segregated, water source-specific eDNA record; whereas when it is increasing (b) exchange is increased between the stream and the hyporheic and riparian zones through hyporheic connectivity, overland flow, and groundwater, increasing the diversity of suspended eDNA at the outlet. 
https://doi.org/10.5194/hess-2019-551

Hydrology and

Preprint. Discussion started: 23 October 2019

(c) Author(s) 2019. CC BY 4.0 License.

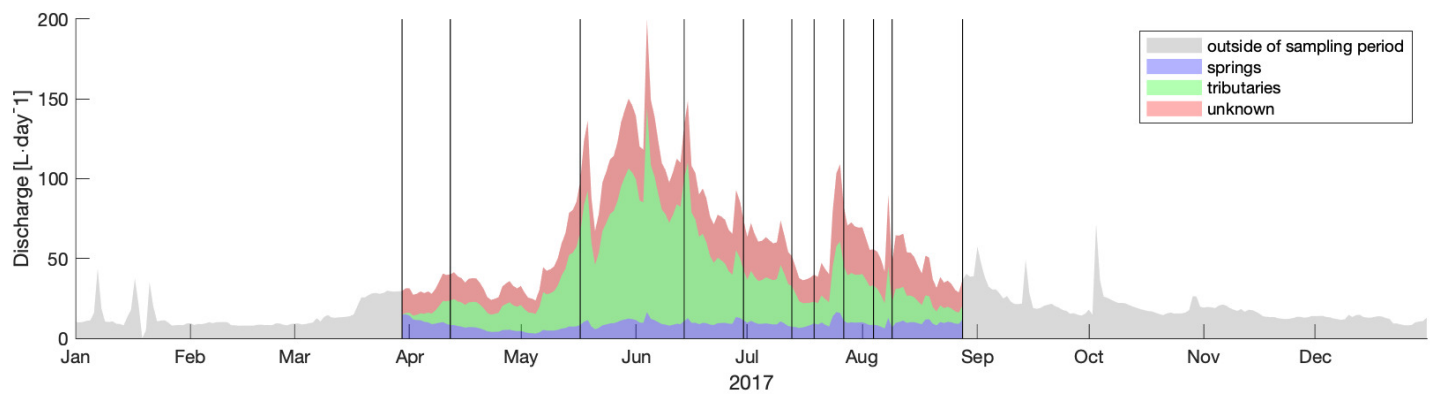

Figure 8. Discharge at outlet decomposed into water origin based on sampled eDNA on 11 days. Contribution of volume from springs is shown in blue, from tributaries in green, and from unknown sources in red. The annual hydrograph is shown for 2017, however volume outside of the sampling period is not computed and is shown in grey. Vertical lines indicate days when eDNA was sampled. 